\title{
Article \\ Spatial Variation of Water Chemistry in Aries River Catchment, Western Romania
}

\author{
Ana Moldovan ${ }^{1,2}$, Maria-Alexandra Hoaghia ${ }^{1, *}$, Anamaria Iulia Török ${ }^{1}$, Marius Roman ${ }^{1}$, Ionut Cornel Mirea ${ }^{3} \mathbb{D}$, \\ Reka Barabas ${ }^{4}$ (D) Valer Micle ${ }^{2}$ (D) and Oana Cadar ${ }^{1}(\mathbb{D}$
}

1 INCDO-INOE 2000, Research Institute for Analytical Instrumentation, 67 Donath Street, 400293 Cluj-Napoca, Romania; ana.moldovan@icia.ro (A.M.); iulia.torok@icia.ro (A.I.T.); marius.roman@icia.ro (M.R.); oana.cadar@icia.ro (O.C.)

2 Faculty of Materials and Environmental Engineering, Technical University, 103-105 Muncii Boulevard, 400641 Cluj-Napoca, Romania; valer.micle@imadd.utcluj.ro

3 Department of Geology and Paleontology, Emil Racovitza Institute of Speleology, Calea 13 Septembrie, 050711 Bucharest, Romania; ionut.cornel.mirea@gmail.com

4 Faculty of Chemistry and Chemical Engineering, Babeş-Bolyai University, 11 Arany Janos Street, 400028 Cluj-Napoca, Romania; reka.barabas@gmail.com

* Correspondence: alexandra.hoaghia@icia.ro

check for updates

Citation: Moldovan, A.; Hoaghia, M.-A.; Török, A.I.; Roman, M.; Mirea, I.C.; Barabas, R.; Micle, V.; Cadar, O. Spatial Variation of Water Chemistry in Aries River Catchment, Western Romania. Appl. Sci. 2021, 11, 6592. https://doi.org/10.3390/app11146592

Academic Editor: Anna Annibaldi

Received: 23 June 2021

Accepted: 15 July 2021

Published: 17 July 2021

Publisher's Note: MDPI stays neutra with regard to jurisdictional claims in published maps and institutional affiliations.

Copyright: (c) 2021 by the authors. Licensee MDPI, Basel, Switzerland. This article is an open access article distributed under the terms and conditions of the Creative Commons Attribution (CC BY) license (https:// creativecommons.org/licenses/by/ $4.0 /)$.
Abstract: This study aims to investigate the quality and vulnerability of surface water (Aries River catchment) in order to identify the impact of past mining activities. For this purpose, the pollution and water quality indices, Piper and Durov plots, as well vulnerability modeling maps were used. The obtained results indicate that the water samples were contaminated with $\mathrm{As}, \mathrm{Fe}, \mathrm{Mn}, \mathrm{Pb}$ and have relatively high concentrations of $\mathrm{SO}_{4}{ }^{2-}, \mathrm{HCO}_{3}{ }^{-}$, $\mathrm{TDS}, \mathrm{Ca}, \mathrm{K}, \mathrm{Mg}$ and high values for the electrical conductivity. Possible sources of the high content of chemicals could be the natural processes or the inputs of the mine drainage. Generally, according to the pollution indices, which were correlated to high concentrations of heavy metals, especially with $\mathrm{Pb}, \mathrm{Fe}$ and $\mathrm{Mn}$, the water samples were characterized by heavy metals pollution. The water quality index classified the studied water samples into five different classes of quality, namely: unsuitable for drinking, poor, medium, good and excellent quality. Similarly, medium, high and very high vulnerability classes were observed. The Durov and Piper plots classified the waters into $\mathrm{Mg}_{-} \mathrm{HCO}_{3}{ }^{-}$and $\mathrm{Ca}-\mathrm{Cl}^{-}$types. The past and present mining activities clearly change the water chemistry and alter the quality of the Aries River, with the water requiring specific treatments before use.

Keywords: water quality; mining areas; pollution indices; Piper diagram; HCA

\section{Introduction}

Worldwide, wastewaters resulted from mining operations (metal oRes. exploitation) are released directly into the river catchments. According to a UNESCO report, $80 \%$ of the wastewaters are discharged directly into the environment without any previous treatments $[1,2]$. The anthropogenic activities influence and alter the quality of water systems, generating negative effects on the aquatic flora and fauna. Hence, the well-functioning of the water system is affected. The presence of high concentrations of heavy metals, organic compounds, insecticides and different other chemical compounds in drinking water sources in waters used in agricultural and household activities affect the human health [3]. These organic and inorganic contaminants are found in different toxic and mobile forms. According to the chemistry and dynamics, they act differently and attach easily to the water ecosystems, influencing the quality and the natural flows of the water systems [4-6].

In Romania, mining activities were blooming during the last 30 years, together with the pollution levels in water, soil and air. The discharge of industrial and mining wastewaters directly into the water streams, without any pretreatment, and the hazards caused environmental disasters (the cyanide spill near Baia Mare, poisoning animals and inducing 
cancer cases in the area of the "Black Town", Copsa-Mica) [7].Since the disaster of Baia Mare area, the mining activities still continued with major impacts on groundwater and surface waters. The Aries River presents a higher vulnerability due to mining activities [8]. The main pollutants of the Aries River are $\mathrm{Cu}, \mathrm{Pb}, \mathrm{Zn}$ and cyanides, due to the acid mine drainage in the mining centers situated along the Aries River [8-10]. Different studies on the Aries River catchment revealed that the areas near the mining centers are still highly polluted and implicitly affected [9-12]. Moreover, the areas crossed by the Aries River represent a petrographic mosaic where the karst landscape is dominant in the upper and middle river catchment (e.g., Bihor Mountains and Muntele Mare areas).

Hence, information regarding the current status of the Aries River is still considered to be essential in order to define and process a suitable decontamination treatment before using the water for drinking purposes, agricultural practices and industrial usages. A part of the water sources monitoring is represented by different and efficient tools such as the water quality indices Appl. to specific points of the water bodies. Two of the most common methods are theHeavy Metal Pollution Index (HPI) and the Heavy Metal Evaluation Index (HEI), used to establish the pollution status of water ecosystems, considering the heavy metals content [13-15]. In order to evaluate the water quality regarding different types of physico-chemical characteristics, Horton proposed the Water Quality Index (WQI) [16]. The WQI is widely used to characterize all types of water bodies. Adimala et al. [17], Wang et al. [18] and Sener et al. [19] assessed the quality of various water systems (in Nanganur, South India and in different areas of China and Turkey) by using the WQI.The results were useful in order to assess the quality of surface water resources as an alternative drinking water possibility.

The aim of this study was: (1) to obtain new and valuable data regarding the current quality status and vulnerability of the Aries River, which is situated near the mining areas; (2) to study the impact of historical mining centers on the surface water quality in all the catchment areas, by determining the physico-chemical properties of waters; and (3) to assess the water quality using various heavy metal pollution indexes.

\section{Methodology}

\subsection{Geological Settings and Description of the Study Area}

The Aries River catchment is part of the Romanian Golden Quadrangle, recognized for the Au, Ag and porphyry copper deposits from Rosia Poieni [20,21]. The Aries River catchment has more than $60 \%$ of its surface developed in the Apuseni Mountains and $\sim 40 \%$ on the Transylvanian Plateau and Feleacului Hills [22]. The Apuseni Mountains are particular mountains in western Romania, characterized by diverse and unique landforms belonging to the Western Carpathians. The Transylvanian Plateau is represented by three distinct units (Somes Plateau, Transylvanian Plain and Tirnavelor Plateau), defined mostly by depressions, low plateaus and hills (the transition areas near mountains) with different geological structu Ref. [23]. Feleacului Hills cover only a small area of the Aries River catchment (north-eastern part), where marly to sandy clay soils appear, intercalated with sands and sandstones. The Aries River springs from Bihor Mountains (near VirfulVirtopu, $1294 \mathrm{~m}$ ) and flows into the MuRes. River (near GuraAriesului village, $317 \mathrm{~m}$ ), with a total length of $\sim 166 \mathrm{~km}$. The Aries River catchment covers several landscapes and landforms of Apuseni Mountains and Transylvanian Plateau (Bihor Mountains in the west part of the country; Metaliferi Mountains in thesouth-central area, Gilau-Muntele Mare in thenorthcentral area of the catchment, Trascau Mountains in the south-east area, Feleacului Hills in the north-east area and Transylvanian Plateau in the east part of the country) [22].

The geological framework is diverse and represented by a variety of formations (from north to south), with basement tectonic units (metamorphic rocks and granites), sedimentary and volcanic cover in the northern area, while Middle Jurassic ophiolites, Late Jurassic volcanic rocks and Late Cretaceous sedimentary deposits dominate the southern part of Apuseni Mountains. Moreover, the groundwater resources in the Aries River catchment are mostly related to karst aquifers developed in limestones or fissured rocks, 
being part of local or discontinuous aquifers (southern part of the basin), while the northern area of the basin is characterized by formations with deep aquifers or without aquifers (Figure 1).

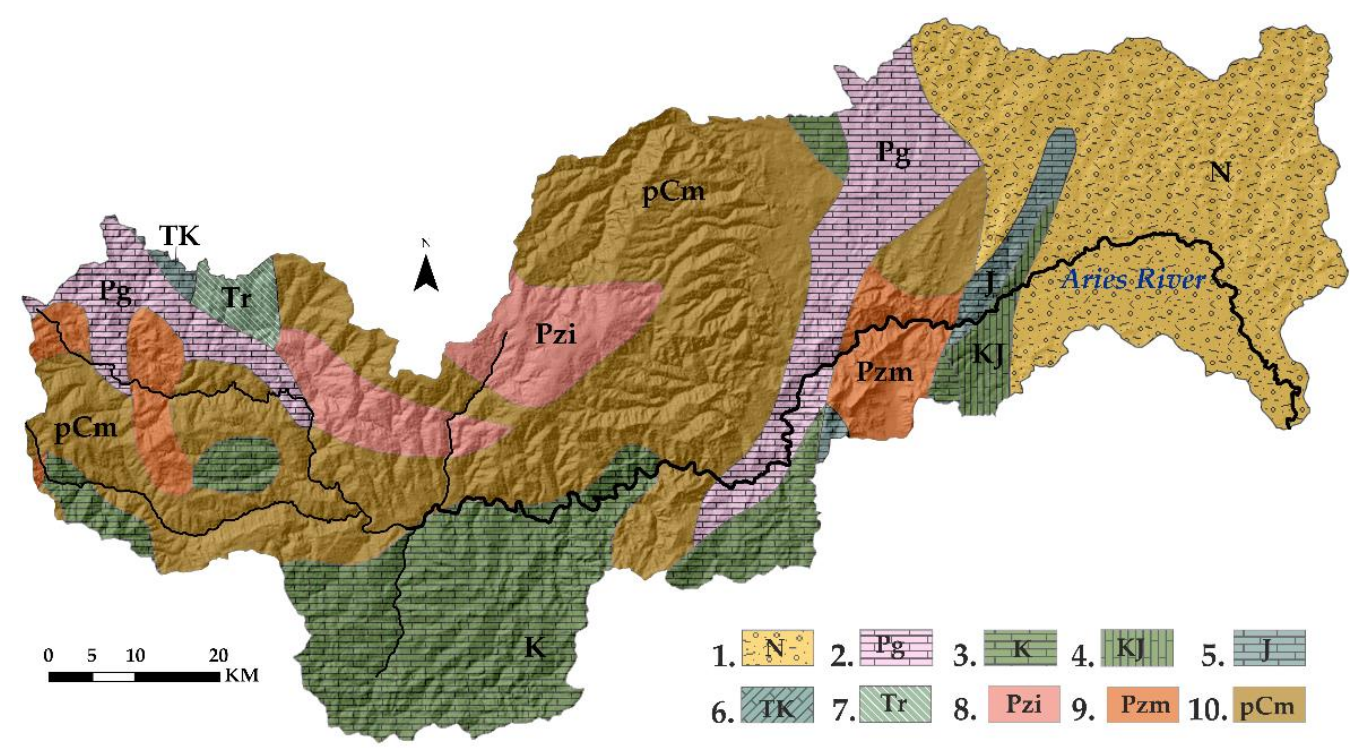

Figure 1. Geologic map of the Aries catchment (modified after Pawlewicz et al., 2002 [24]). 1. Neogene; 2. Paleogene; 3. Cretaceous; 4. Cretaceous-Jurassic; 5. Jurassic; 6. Triassic-Cretaceous; 7. Triassic; 8. Paleozoic intrusive rocks; 9. Paleozoic metamorphic rocks; 10. Undivided Precambrian.

The most significant exploitations conducted in the catchment area are Rosia Montana, Rosia Poieni, Baia de Aries and Iara (Table 1) $[21,25,26]$. Tailings resulting from the oRes. extractions were stored in several tailing ponds, while all the wastewaters resulted from the mining activities and secondary processing of the oRes. are discharged into the tributaries of the Aries Rivers (Figure 2).Most of the mining and ore processing facilities were demolished or conserved;however, some of them were simply abandoned [27].At present, the open-cast mine Rosia Poieni is the only unity in operation, although reopening the exploitation of gold and silver oRes. at Rosia Montana has been largely debated during the last few years.

Table 1. Characteristics of the main tailing impoundments located in the Aries Rciver catchment [27].

\begin{tabular}{|c|c|c|c|c|c|}
\hline & Deposit Type & $\begin{array}{l}\text { Extraction } \\
\text { Technique }\end{array}$ & $\begin{array}{l}\text { Current } \\
\text { Status }\end{array}$ & $\begin{array}{c}\text { Tailing } \\
\text { Impoundment }\end{array}$ & 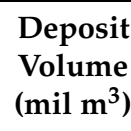 \\
\hline \multirow{2}{*}{ Rosia Montana } & \multirow{2}{*}{$\begin{array}{l}\text { Au ores } \\
\text { Ag ores } \\
\text { Cu ores }\end{array}$} & \multirow{2}{*}{ Open-pit gold mine } & \multirow{2}{*}{$\begin{array}{c}\text { Closed } \\
\text { since } 2006\end{array}$} & Seliste & 6.60 \\
\hline & & & & Gura Rosie & 5.80 \\
\hline \multirow{2}{*}{ Rosia Poieni } & \multirow{2}{*}{ Porphyritic $\mathrm{Cu}$} & \multirow{2}{*}{$\begin{array}{l}\text { Open-pit copper } \\
\text { mine }\end{array}$} & \multirow{2}{*}{ Open } & Stefanca & 11.0 \\
\hline & & & & Sesei & 66.0 \\
\hline \multirow{3}{*}{ Baia de Aries } & \multirow{3}{*}{$\begin{array}{l}\text { Lead-zinc ferrous } \\
\text { Gold-silver ferrous }\end{array}$} & \multirow{3}{*}{ Gallery mine } & \multirow{3}{*}{$\begin{array}{c}\text { Closed } \\
\text { since } 2004\end{array}$} & Cutii & 1.62 \\
\hline & & & & Sartas & 2.86 \\
\hline & & & & Brazesti & 3.47 \\
\hline \multirow{2}{*}{ Iara } & \multirow{2}{*}{$\begin{array}{l}\text { Fe ores } \\
\text { Mg ores }\end{array}$} & \multirow{2}{*}{ Open pit mine } & \multirow{2}{*}{$\begin{array}{c}\text { Closed } \\
\text { since } 2005\end{array}$} & Baisoara & 3.33 \\
\hline & & & & FagetulIerii & 1.56 \\
\hline
\end{tabular}




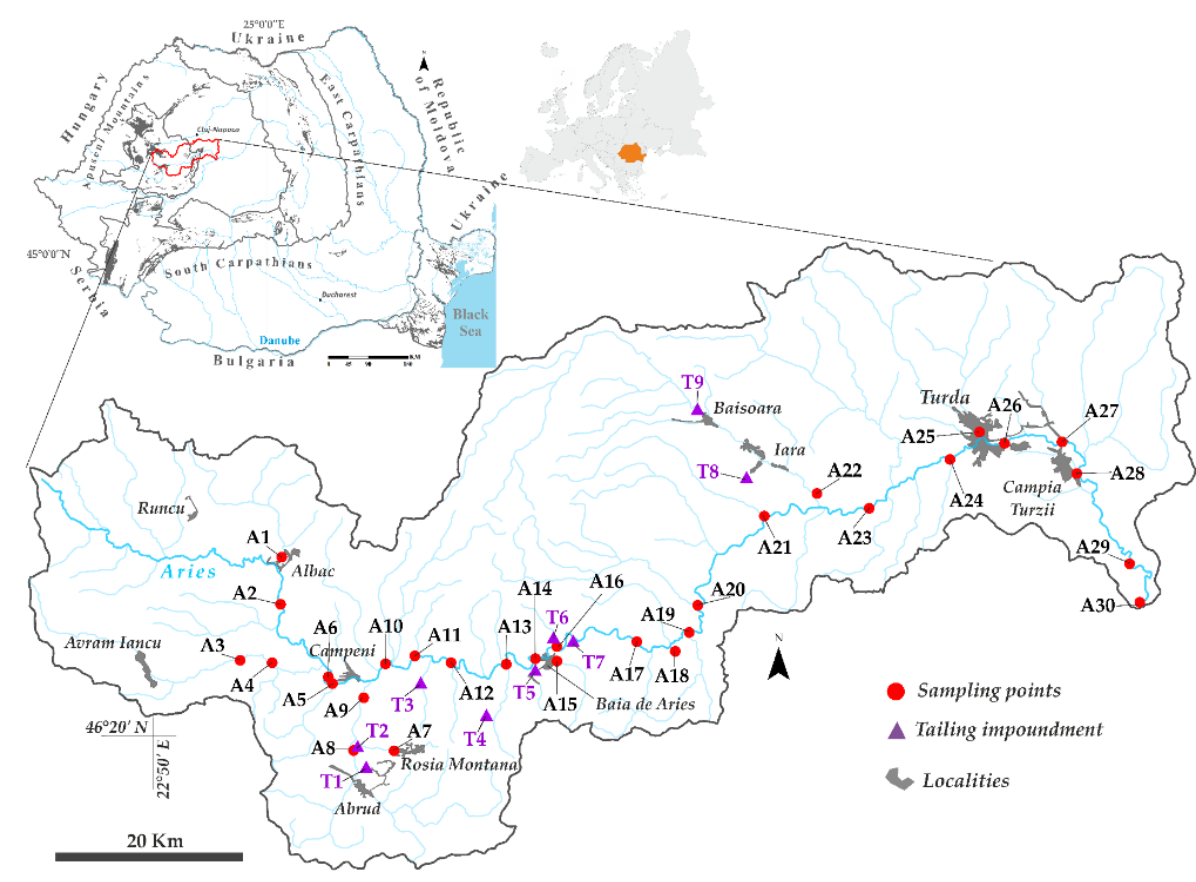

Figure 2. Location of the sampling points and the main tailings impoundments in the Aries River catchment.

Over the years, several remediation measuRes. were taken, but the resulting wastes of the long periods of mining activities and their poor management have led to a significant deterioration of the quality of the natural environment $[9,10,27,28]$.

\subsection{Sampling and Analytical Procedures}

The study area was selected based on the impacts generated by the mining and industrial activities on the water resources (Figure 2). To evaluate the quality of the surface water, a field survey was conducted across the Aries River catchment. A number of 30 samples were collected from the mainstream (17 samples-A6, A12, A15-A30) and from the tributaries (13 samples-A1-A5, A7-A11, A13, A14) in November 2018.

The samples were collected with a "Grab" device submerged at $20 \mathrm{~cm}$ under the water in polyethylene bottles pre-washed with $0.1 \mathrm{~N}^{-N_{3}}$. The water samples were kept at $4{ }^{\circ} \mathrm{C}$ until the physico-chemical analysis, but no longer than $24 \mathrm{~h}$.

The $\mathrm{pH}$ and electrical conductivity (EC) were measured on-field by using a portable 350I multiparameter (WTW, Weilheim, Germany). The total dissolved solids (TDS) were determined by gravimetry, while bicarbonates $\left(\mathrm{HCO}_{3}{ }^{-}\right)$were determined by titration with $0.1 \mathrm{~N} \mathrm{HCl}$ in the presence of bromocresol green indicator. The anions $\left(\mathrm{F}^{-}, \mathrm{Cl}^{-}, \mathrm{NO}_{2}{ }^{-}\right.$, $\mathrm{NO}_{3}{ }^{-}, \mathrm{PO}_{4}{ }^{3-}, \mathrm{SO}_{4}{ }^{2-}$ ) concentration was measured by ion chromatography using an IC 761 Compact equipment (Metrohm, Herisau, Switzerland) after filtering the samples with $0.45 \mu \mathrm{m}$ cellulose acetate membrane filters(Isolab, Eschau, Germany), used with no further purification treatments. Samples were directed injected into the equipment, characterized by a flow of $0.7 \mathrm{~mL} / \mathrm{min}, 7.5 \mathrm{mPa}$ pressure and $15.0 \mu \mathrm{S} / \mathrm{cm}$ electrical conductivity. Anions were separated through the anions exchange column and detected with the help of a conductivity detector [29].

For the determination of metals, the samples were filtered with $0.45 \mu \mathrm{m}$ cellulose acetate membrane and acidified with $65 \% \mathrm{HNO}_{3}$. The major cations ( $\mathrm{Fe}, \mathrm{Na}, \mathrm{Mg}, \mathrm{K}$ and $\mathrm{Ca}$ ) were analyzed through an inductively coupled plasma optical emission spectrometer(ICPOES, Perkin Elmer, Waltham, MA, USA), while the trace metals $(\mathrm{Ni}, \mathrm{Cr}, \mathrm{Co}, \mathrm{Cu}, \mathrm{Zn}$, $\mathrm{Cd}, \mathrm{Pb}, \mathrm{Mn}, \mathrm{Ba}, \mathrm{Al}, \mathrm{Sr}$ and $\mathrm{As}$ ) were analyzed through an inductively coupled mass spectrometer (ELAN DRC II ICP-MS, Perkin Elmer, Waltham, MA, USA), due to the very low sensitivity of the equipment [29]. The instruments calibration was performed using 
analytical curves prepared with a multi-element standard solution from ICP Multi-Element Standard Solution IV (CertiPUR Merck, Darmstadt, Germany) in case of the ICP-OES and PerkinElmer Instrument Calibration Standard 3 in case of the ICP-MS.

In order to ensure the quality of the results, calibration standards, duplicate samples and procedural lab blanks were prepared and determined, in concordance with Moldovan et al. [30]. The accuracy of the metal determinations was tested using the $1643 \mathrm{f}$ NIST certified reference material (National Institute of Standards and Technology, Gaithersburg, MD, USA), while the anions were determined according to the IC1 Multi-element standard (CertiPUR Merck, Darmstadt, Germany). The mean recoveries ranged between $94 \%$ and $105 \%$ for the metals and between $89 \%$ and $102 \%$ for the anions.

All reagents were of analytical grade and were used without any further purification. Ultrapure water from a Millipore system (Molsheim, France) was used for all dilutions.

\subsection{Pollution Assessment}

The Heavy Metal Pollution Index (HPI) is a rating model that provides the aggregate influence of individual heavy metals on the overall quality of different water types [31,32]. Seven heavy metals $(\mathrm{Cd}, \mathrm{Cu}, \mathrm{Fe}, \mathrm{Mn}, \mathrm{Ni}, \mathrm{Pb}$ and $\mathrm{Zn}$ ) were used for the calculation of HPI. The HPI was computed in two steps, according to Equations (1) and (2) [33]:

$$
\begin{gathered}
H P I=\frac{\sum_{i=1}^{n}\left(Q_{i} W_{i}\right)}{\sum_{i=1}^{n} W_{i}} \\
Q_{i}=\frac{M_{i}}{S_{i}} \times 100
\end{gathered}
$$

where, $Q_{i}$ is the sub-index of the $i$ th parameter, $W_{i}$ is the unit weightage of the $i$ th parameter and $n$ is the number of the considered chemical parameters. $M_{i}$ and $S_{i}$ are the concentration of the monitored ith parameter and the standard maximum allowable values (mg/L), according to the Romanian Regulation and to the European Directive concerning water quality $[34,35]$.

HPI scoRes. below the threshold (HPI < 100) indicate low pollution with heavy metals, while scoRes. higher than 100 (HPI > 100) suggest that the water is unsuitable for consumption and, when consumed, it causes harmful health consequences. The case of an HPI > 100 indicates pollution with heavy metals [36].

The Heavy Metal Evaluation Index (HEI) is another tool for assessing water quality, offering an insight into the overall quality of water sources with respect to the heavy metals content, which is consistent with the HPI method. The HEI iscalculated based on Equation (3), according to Bhuiyan et al. [37], Edet and Offiong [38]. The surface water can be classified based on the HEI scores, as follows: surface waters with a low degree of pollution $(\mathrm{HEI}<10)$, waters with a medium degree of pollution $(10<\mathrm{HEI}<20)$ and waters with a high pollution level (HEI > 20) [39].

$$
H E I=\sum_{i=1}^{n} \frac{M_{i}}{S_{i}}
$$

where $M_{i}$ is the determined concentration of the $i$ th parameter and $S_{i}$ represents the maximum allowable concentration (MAC) of the parameters. In the present study, $S_{i}$ values were considered according to the Romanian and International Regulations, namely the Minister Order 161/2006/OD and Directive 2008/32/CE, regarding the quality of surface water resources [34,35].

\subsection{Water Quality Index (WQI)}

One of the most effective tools in evaluating the quality of waters is represented by the Water Quality Index (WQI), showing the risk posed by the pollutants present in the water constituents matrix [16]. This method provides an overview of the quality status characterizing various water resources. The WQI is computed in four steps: (a) the 
assignment of the weights $\left(w_{i}\right)$ for each physico-chemical parameter based on its importance for the quality of the surface water (Table 2); (b) the calculation of the relative weight $\left(W_{i}\right)$ using Equation (4); (c) establishing the quality rating $\left(q_{i}\right)$ according to Equation (5); (d) the calculation of the subindex for each physico-chemical parameter $\left(S I_{i}\right)$ and aggregation into the WQI. Equations (6) and (7) are Appl. in the last step of the method [16].

$$
\begin{aligned}
& W_{i}=\frac{w_{i}}{\sum_{i=1}^{n} w_{i}} \\
& q_{i}=\frac{w_{i}}{S_{i}} \times 100 \\
& S I_{i}=W_{i} \times q_{i} \\
& \mathrm{WQI}=\sum_{i=1}^{n} S I_{i}
\end{aligned}
$$

where, $w_{i}$ is the weight of each parameter, $W_{i}$ is the relative weight, $q_{i}$ represents the quality rating for each physico-chemical parameter, $C_{i}$ and $S_{i}$ represent the concentration and the guideline value according to the drinking water quality guidelines established by the Minister Order 161/2006/OD and the Directive 2008/32/CE [34,35], $S I_{i}$ represents the subindex of the $i$ th parameter.

Table 2. List of the parameter values $\left(S_{i}\right)$, weights $\left(w_{i}\right)$ and relative weights $\left(W_{i}\right)$ used for the calculation of the WQI.

\begin{tabular}{ccccc}
\hline Parameter & Unit & $S_{i}{ }^{*}$ & $w_{i}$ & $W_{i}$ \\
\hline $\mathrm{pH}$ & - & $6.5-8.5$ & 3 & 0.06 \\
$\mathrm{TDS}$ & $\mathrm{mg} / \mathrm{L}$ & 1300 & 5 & 0.10 \\
$\mathrm{Ca}$ & $\mathrm{mg} / \mathrm{L}$ & 300 & 4 & 0.08 \\
$\mathrm{Mg}$ & $\mathrm{mg} / \mathrm{L}$ & 200 & 4 & 0.08 \\
$\mathrm{Na}$ & $\mathrm{mg} / \mathrm{L}$ & 200 & 2 & 0.04 \\
$\mathrm{Cl}$ & $\mathrm{mg} / \mathrm{L}$ & 300 & 4 & 0.08 \\
$\mathrm{NO}_{3}{ }^{-}$ & $\mathrm{mg} / \mathrm{L}$ & 11.2 & 5 & 0.10 \\
$\mathrm{SO}_{4}{ }^{2-}$ & $\mathrm{mg} / \mathrm{L}$ & 300 & 3 & 0.06 \\
$\mathrm{As}$ & $\mathrm{mg} / \mathrm{L}$ & 0.100 & 3 & 0.06 \\
$\mathrm{Mn}$ & $\mathrm{mg} / \mathrm{L}$ & 0.100 & 3 & 0.06 \\
$\mathrm{Fe}$ & $\mathrm{mg} / \mathrm{L}$ & 0.200 & 3 & 0.06 \\
$\mathrm{~Pb}$ & $\mathrm{mg} / \mathrm{L}$ & 0.050 & 3 & 0.06 \\
$\mathrm{Ni}$ & $\mathrm{mg} / \mathrm{L}$ & 0.100 & 3 & 0.06 \\
$\mathrm{Zn}$ & $\mathrm{mg} / \mathrm{L}$ & 1.00 & 3 & 0.06 \\
$\mathrm{Cu}$ & $\mathrm{mg} / \mathrm{L}$ & 1.00 & 3 & $\sum W_{i}=1.00$ \\
\hline
\end{tabular}

* Ministerial Order 161/2006/OD and Directive 2008/32/CE [34,35].

The WQI scoRes. classify the studied waters into five different quality categories: (a) excellent-suitable for drinking, irrigation and industrial usages, WQI = 0-25; (b) goodsuitable for domestic, irrigation and industrial usages, WQI = 26-50; (c) poor-suitable for irrigation and industrial usages, WQI $=51-75$; (d) very poor-suitable for irrigation usage, WQI $=76-100$ and (e) unsuitable for drinking purposes and restricted for irrigation, WQI $>100[40,41]$.

\subsection{Graphical Approaches of the Quality Status}

Piper and Durov diagrams were generated by using AqQa software (free version). The studied water samples were classified, based on the specific concentrations of physicochemical parameters. For the Piper diagram, specific indicators such as $\mathrm{Cl}^{-}, \mathrm{SO}_{4}{ }^{2-}, \mathrm{Ca}$, $\mathrm{Mg}, \mathrm{Na}, \mathrm{K}, \mathrm{HCO}_{3}{ }^{-}$and $\mathrm{CO}_{3}{ }^{2-}$, concentrations were used, while for the Durov plot, the $\mathrm{pH}$ and TDS content were added [42,43]. 
To highlight the correlations and similarities among the physico-chemical indicators, the agglomerative hierarchical cluster analysis (HCA) based on the Ward method (Euclidean distance) was assessed. The method was Appl. using XLSTAT software.

\subsection{Interpolation Methods Used for Representation of HPI, HEI and WQI}

In order to assess the polluted areas, several interpolation methods from ArcGis 10.1 spatial analyst were used: IDW, Ordinary Kriging (OK) and Empirical Bayesian Kriging (EBK). From these methods, only the EBK method was appropriate to represent the contaminated areas regarding the number and the distribution of the sampling points in the Aries catchment. EBK was reported to have good results with small datasets regarding the contaminated areas [44]. However, in order to reduce the bias, the EBK was Appl. only to the mainstream and to the floodplain area around the Aries River (and few tributaries) for determining the polluted areas.

\section{Results}

\subsection{Water Quality Assessment}

The monitoring study was conducted in the rainy season (November 2018), which is more susceptible to indicate the actual values of the studied physico-chemical indicators, compared to the warm season, when due to the drought, the concentrations are higher. This season was not characterized by high precipitation amounts; therefore, the dissolution of the physico-chemical compounds and the low concentrations of the chemicals due to the washing by precipitations should be avoided. The total number of sampling sites was set to 30 points, randomly chosen, in order to analyze a number of 27 physicochemical parameters. The obtained results, along with their statistical data, are presented in Tables 3 and 4.

The $\mathrm{pH}$ of the water samples (7.2-8.7) was within the normal limits except for three sample points: A3 (9.0), A7 (2.8) and A13 (5.2), which were indicating a strong variation of the water character. The slightly alkaline $\mathrm{pH}$ values are explained by the dissolution of carbonate minerals [29], while the strong acid character can be attributed to the drainage of the acid mine wastewaters near two mining areas. Acid mine drainage is an important source of surface water pollution worldwide. Luis et al. (2009) reported the effects of the mine drainage into a hydrographic river catchment, in an area characterized by the abundance of sulfide ores, in Portugal [45].

Generally, tailings coming from mineral extraction areas are considered major sources of heavy metals and other chemical compounds (cyanide, sulfuric acid, ammonium nitrate). These chemicals are used during the separation processes of sterile from the ore and excavating machines. However, the natural geological units could also be the source of high amounts of toxic metals (e.g., Cd from sphalerite, $\mathrm{Zn}$ from sphalerite and As from oxidation of sulfide minerals pyrite) [46].

The analyzed surface water samples showed a low spatial variation of heavy metals (such as $\mathrm{Cd}, \mathrm{Mn}, \mathrm{Ni}$ and $\mathrm{As}$ ). However, important differences were observed in the cases of the $\mathrm{Fe}, \mathrm{Cr}, \mathrm{Co}, \mathrm{Zn}, \mathrm{Sr}, \mathrm{Ba}$, and $\mathrm{Al}$ variability. It was observed that the metal concentrations varied in different sampling locations (Figure 3). Samples A9-A13 were characterized by the highest concentrations of $\mathrm{As}, \mathrm{Fe}, \mathrm{Mn}$ and $\mathrm{Pb}$, exceeding the thresholds up to four times. The waters were sampled next to the tailing impoundments and connected to Rosia Montana and Rosia Poieni mining areas, indicating a significant impact on the chemical composition of the Aries River catchment over time. In the proximity of ValeaSesii tailing impoundment, A12 has the highest As, Fe and Mn concentrations, exceeding the thresholds. All samples were contaminated with $\mathrm{Pb}$, with values ranging between 0.041 and 0.227 , except for A19, which has a significant concentration of $\mathrm{Pb}$ as well, but below the threshold. 
Table 3. Trend of spatial variation of the physico-chemical parameters analyzed in the Aries River water samples.

\begin{tabular}{|c|c|c|c|c|c|c|c|c|}
\hline & $\mathrm{pH}$ & $\begin{array}{c}\mathrm{CE} \\
(\mu \mathrm{s} / \mathrm{cm})\end{array}$ & $\begin{array}{c}\text { TDS } \\
(\mathrm{mg} / \mathrm{L})\end{array}$ & $\begin{array}{c}\mathrm{HCO}_{3}^{-} \\
(\mathrm{mg} / \mathrm{L})\end{array}$ & $\mathbf{F}^{-}$ & $\mathrm{Cl}^{-}$ & $\mathrm{NO}_{3}{ }^{-}$ & $\mathrm{SO}_{4}{ }^{3-}$ \\
\hline A1 & 7.6 & 188 & 167 & 87.6 & 0.06 & 8.09 & 1.18 & 4.78 \\
\hline A2 & 7.5 & 202 & 154 & 97.6 & 0.06 & 8.22 & 1.22 & 5.82 \\
\hline A3 & 8.7 & 173 & 162 & 94.2 & 0.08 & 8.61 & 1.02 & 6.83 \\
\hline A4 & 8.3 & 140 & 159 & 73.6 & 0.06 & 1.91 & 0.99 & 5.67 \\
\hline A5 & 8.2 & 157 & 168 & 84.5 & 0.07 & 2.13 & 1.08 & 5.74 \\
\hline A6 & 9.0 & 168 & 178 & 80.6 & 0.06 & 6.52 & 1.22 & 5.13 \\
\hline A7 & 2.8 & 901 & 952 & 302 & 0.15 & 42.9 & 0.67 & 465 \\
\hline A8 & 7.2 & 824 & 485 & 122 & 0.15 & 12.8 & 0.77 & 6.82 \\
\hline A10 & 7.2 & 620 & 412 & 62.4 & 0.12 & 15.0 & 0.88 & 202 \\
\hline A11 & 7.4 & 576 & 405 & 79.3 & 0.11 & 15.5 & 0.50 & 194 \\
\hline A12 & 7.6 & 222 & 231 & 90.7 & 0.08 & 7.65 & 2.33 & 32.2 \\
\hline A13 & 5.2 & 1348 & 712 & 262 & 0.33 & 45.8 & 2.45 & 208 \\
\hline A14 & 8.0 & 495 & 408 & 171 & 0.13 & 19.1 & 0.58 & 93.2 \\
\hline A15 & 8.0 & 357 & 312 & 72.1 & 0.12 & 14.2 & 1.11 & 87.3 \\
\hline A16 & 8.1 & 287 & 249 & 83.6 & 0.11 & 8.21 & 1.27 & 56.0 \\
\hline A17 & 8.0 & 309 & 246 & 89.8 & 0.13 & 8.41 & 1.19 & 62.5 \\
\hline A18 & 7.9 & 318 & 258 & 88.4 & 0.13 & 8.77 & 1.20 & 66.2 \\
\hline A19 & 8.0 & 320 & 263 & 84.2 & 0.12 & 9.00 & 1.13 & 68.0 \\
\hline A20 & 8.0 & 251 & 197 & 109 & 0.09 & 10.8 & 1.38 & 17.4 \\
\hline A22 & 8.1 & 283 & 227 & 98.7 & 0.10 & 6.82 & 1.41 & 43.8 \\
\hline $\mathrm{A} 23$ & 8.1 & 328 & 234 & 113 & 0.10 & 9.26 & 1.53 & 56.4 \\
\hline A24 & 8.2 & 322 & 274 & 108 & 0.10 & 17.6 & 1.72 & 59.8 \\
\hline A25 & 8.4 & 414 & 303 & 126 & 0.11 & 21.5 & 1.99 & 66.5 \\
\hline A26 & 8.5 & 478 & 278 & 123 & 0.11 & 21.5 & 1.91 & 68.3 \\
\hline A27 & 8.4 & 417 & 287 & 131 & 0.12 & 21.7 & 1.88 & 66.0 \\
\hline A28 & 8.5 & 405 & 273 & 114 & 0.12 & 20.8 & 1.64 & 66.3 \\
\hline A29 & 8.6 & 384 & 267 & 108 & 0.11 & 18.8 & 1.26 & 67.7 \\
\hline A30 & 8.3 & 368 & 262 & 117 & 0.13 & 14.6 & 1.37 & 63.5 \\
\hline Min & 2.8 & 140 & 154 & 62.4 & 0.06 & 1.91 & 0.50 & 4.78 \\
\hline Max & 9.0 & 1348 & 952 & 302 & 0.33 & 45.8 & 2.50 & 465 \\
\hline Average & 7.7 & 400 & 305 & 118 & 0.11 & 14.3 & 1.31 & 80.5 \\
\hline MAC * & $6.5-8.5$ & - & 1300 & - & - & 300 & 11.2 & 300 \\
\hline
\end{tabular}

* Ministerial Order 161/2006/OD and Directive 2008/32/CE [34,35]. 
Table 4. The element concentrations (mg/ L) in the surface water samples (A1-A30).

\begin{tabular}{|c|c|c|c|c|c|c|c|c|c|c|c|c|c|c|c|c|c|}
\hline & $\mathrm{Fe}$ & $\mathrm{Ni}$ & $\mathrm{Cr}$ & Co & $\mathrm{Cu}$ & $\mathrm{Zn}$ & $\mathrm{Cd}$ & $\mathrm{Pb}$ & $\mathrm{Na}$ & Mg & K & $\mathrm{Ca}$ & Mn & $\mathrm{Ba}$ & Al & $\mathrm{Sr}$ & As \\
\hline A1 & 0.041 & 0.069 & 0.017 & 0.064 & 0.088 & 0.032 & 0.028 & 0.080 & 4.19 & 2.92 & 0.639 & 25.3 & 0.032 & 0.034 & 0.038 & 0.023 & 0.001 \\
\hline A2 & 0.058 & 0.066 & 0.018 & 0.064 & 0.088 & 0.033 & 0.026 & 0.090 & 4.29 & 3.07 & 0.677 & 27.8 & 0.033 & 0.036 & 0.033 & 0.027 & 0.001 \\
\hline A3 & 0.169 & 0.065 & 0.020 & 0.064 & 0.087 & 0.038 & 0.027 & 0.093 & 4.36 & 3.32 & 0.689 & 26.3 & 0.036 & 0.038 & 0.121 & 0.035 & 0.001 \\
\hline A5 & 0.077 & 0.066 & 0.015 & 0.063 & 0.092 & 0.011 & 0.026 & 0.074 & 2.04 & 2.61 & 0.682 & 22.4 & 0.033 & 0.040 & 0.038 & 0.027 & 0.001 \\
\hline A6 & 0.066 & 0.067 & 0.020 & 0.052 & 0.084 & 0.010 & 0.030 & 0.063 & 3.49 & 2.88 & 1.41 & 21.2 & 0.036 & 0.029 & 0.036 & 0.028 & 0.001 \\
\hline A7 & 0.807 & 0.064 & 0.035 & 0.065 & 0.084 & 0.038 & 0.028 & 0.227 & 7.63 & 21.6 & 8.69 & 278 & 0.038 & 0.039 & 0.041 & 0.292 & 0.002 \\
\hline A8 & 0.028 & 0.038 & 0.033 & 0.064 & 0.047 & 0.042 & 0.020 & 0.058 & 5.21 & 4.75 & 4.37 & 40.6 & 0.048 & 0.042 & 0.038 & 0.290 & 0.001 \\
\hline A10 & 0.294 & 0.072 & 0.028 & 0.067 & 0.100 & 0.079 & 0.027 & 0.104 & 11.8 & 10.6 & 5.06 & 72.8 & 0.522 & 0.051 & 0.128 & 0.290 & 0.002 \\
\hline A11 & 0.076 & 0.081 & 0.031 & 0.069 & 0.091 & 0.240 & 0.026 & 0.110 & 12.1 & 11.2 & 4.76 & 75.1 & 0.672 & 0.054 & 0.083 & 0.296 & 0.002 \\
\hline A12 & 0.366 & 0.070 & 0.027 & 0.062 & 0.087 & 0.049 & 0.028 & 0.202 & 5.50 & 4.73 & 1.65 & 31.5 & 0.981 & 0.029 & 0.087 & 0.081 & 0.020 \\
\hline A13 & 0.070 & 0.066 & 0.028 & 0.060 & 0.090 & 0.057 & 0.026 & 0.133 & 10.2 & 5.88 & 1.88 & 170 & 0.273 & 0.028 & 0.071 & 0.088 & 0.002 \\
\hline A14 & 0.083 & 0.063 & 0.087 & 0.060 & 0.092 & 0.036 & 0.025 & 0.107 & 11.2 & 11.4 & 2.92 & 65.9 & 0.043 & 0.053 & 0.069 & 0.405 & 0.002 \\
\hline A15 & 0.072 & 0.063 & 0.027 & 0.061 & 0.090 & 0.030 & 0.026 & 0.100 & 5.88 & 8.16 & 3.04 & 42.7 & 0.055 & 0.042 & 0.062 & 0.348 & 0.002 \\
\hline A16 & 0.052 & 0.065 & 0.023 & 0.066 & 0.088 & 0.024 & 0.027 & 0.096 & 5.65 & 3.94 & 2.10 & 38.4 & 0.246 & 0.032 & 0.017 & 0.097 & 0.002 \\
\hline A17 & 0.099 & 0.069 & 0.016 & 0.062 & 0.092 & 0.027 & 0.030 & 0.113 & 6.43 & 4.10 & 2.48 & 41.9 & 0.046 & 0.032 & 0.142 & 0.104 & 0.002 \\
\hline A18 & 0.124 & 0.064 & 0.020 & 0.060 & 0.091 & 0.030 & 0.031 & 0.107 & 6.50 & 5.03 & 2.67 & 40.8 & 0.048 & 0.033 & 0.097 & 0.097 & 0.002 \\
\hline A20 & 0.078 & 0.061 & 0.028 & 0.050 & 0.086 & 0.030 & 0.029 & 0.094 & 3.56 & 6.15 & 1.99 & 30.8 & 0.048 & 0.035 & 0.230 & 0.069 & 0.003 \\
\hline A21 & 0.064 & 0.060 & 0.054 & 0.055 & 0.090 & 0.027 & 0.028 & 0.088 & 4.22 & 5.87 & 2.02 & 32.7 & 0.042 & 0.035 & 0.062 & 0.070 & 0.002 \\
\hline A22 & 0.037 & 0.059 & 0.023 & 0.063 & 0.094 & 0.023 & 0.028 & 0.069 & 4.95 & 5.56 & 2.07 & 36.7 & 0.034 & 0.036 & 0.079 & 0.089 & 0.002 \\
\hline A23 & 0.075 & 0.058 & 0.023 & 0.060 & 0.090 & 0.027 & 0.022 & 0.093 & 6.78 & 5.74 & 2.47 & 43.3 & 0.033 & 0.035 & 0.119 & 0.119 & 0.003 \\
\hline A24 & 0.055 & 0.062 & 0.042 & 0.056 & 0.090 & 0.025 & 0.021 & 0.090 & 10.2 & 6.43 & 3.18 & 45.3 & 0.033 & 0.038 & 0.082 & 0.145 & 0.003 \\
\hline A25 & 0.042 & 0.068 & 0.031 & 0.051 & 0.091 & 0.026 & 0.022 & 0.090 & 14.1 & 7.17 & 4.11 & 48.5 & 0.033 & 0.040 & 0.094 & 0.176 & 0.003 \\
\hline A26 & 0.067 & 0.070 & 0.025 & 0.057 & 0.090 & 0.026 & 0.026 & 0.074 & 14.5 & 7.02 & 4.28 & 48.8 & 0.030 & 0.037 & 0.088 & 0.176 & 0.003 \\
\hline A27 & 0.078 & 0.070 & 0.029 & 0.061 & 0.089 & 0.029 & 0.026 & 0.050 & 14.6 & 7.09 & 4.24 & 48.9 & 0.033 & 0.035 & 0.109 & 0.176 & 0.004 \\
\hline A28 & 0.067 & 0.070 & 0.027 & 0.057 & 0.088 & 0.031 & 0.026 & 0.088 & 12.8 & 7.04 & 3.22 & 46.3 & 0.032 & 0.036 & 0.120 & 0.166 & 0.003 \\
\hline A29 & 0.067 & 0.069 & 0.025 & 0.057 & 0.088 & 0.036 & 0.025 & 0.104 & 11.3 & 6.29 & 3.24 & 45.8 & 0.034 & 0.039 & 0.132 & 0.157 & 0.003 \\
\hline $\mathrm{A} 30$ & 0.047 & 0.069 & 0.023 & 0.059 & 0.090 & 0.026 & 0.024 & 0.066 & 9.74 & 6.12 & 3.29 & 46.2 & 0.036 & 0.036 & 0.077 & 0.153 & 0.003 \\
\hline Min & 0.028 & 0.038 & 0.017 & 0.050 & 0.047 & 0.010 & 0.020 & 0.041 & 1.90 & 2.50 & 0.59 & 20.2 & 0.030 & 0.028 & 0.033 & 0.023 & 0.001 \\
\hline Max & 0.807 & 0.081 & 0.087 & 0.069 & 0.108 & 0.240 & 0.031 & 0.227 & 14.6 & 21.6 & 8.69 & 278 & 0.981 & 0.054 & 0.230 & 0.405 & 0.020 \\
\hline Average & 0.124 & 0.062 & 0.036 & 0.061 & 0.093 & 0.044 & 0.026 & 0.102 & 7.77 & 6.99 & 2.96 & 56.0 & 0.143 & 0.042 & 0.091 & 0.154 & 0.003 \\
\hline $\mathrm{MAC}^{*}$ & 2.00 & 0.100 & 0.250 & 0.100 & 0.100 & 1.00 & 0.050 & 0.050 & 200 & 200 & - & 300 & 1.00 & 1.00 & - & - & 0.100 \\
\hline
\end{tabular}

* Ministerial Order 161/2006/OD and Directive 2008/32/CE [34,35]. 


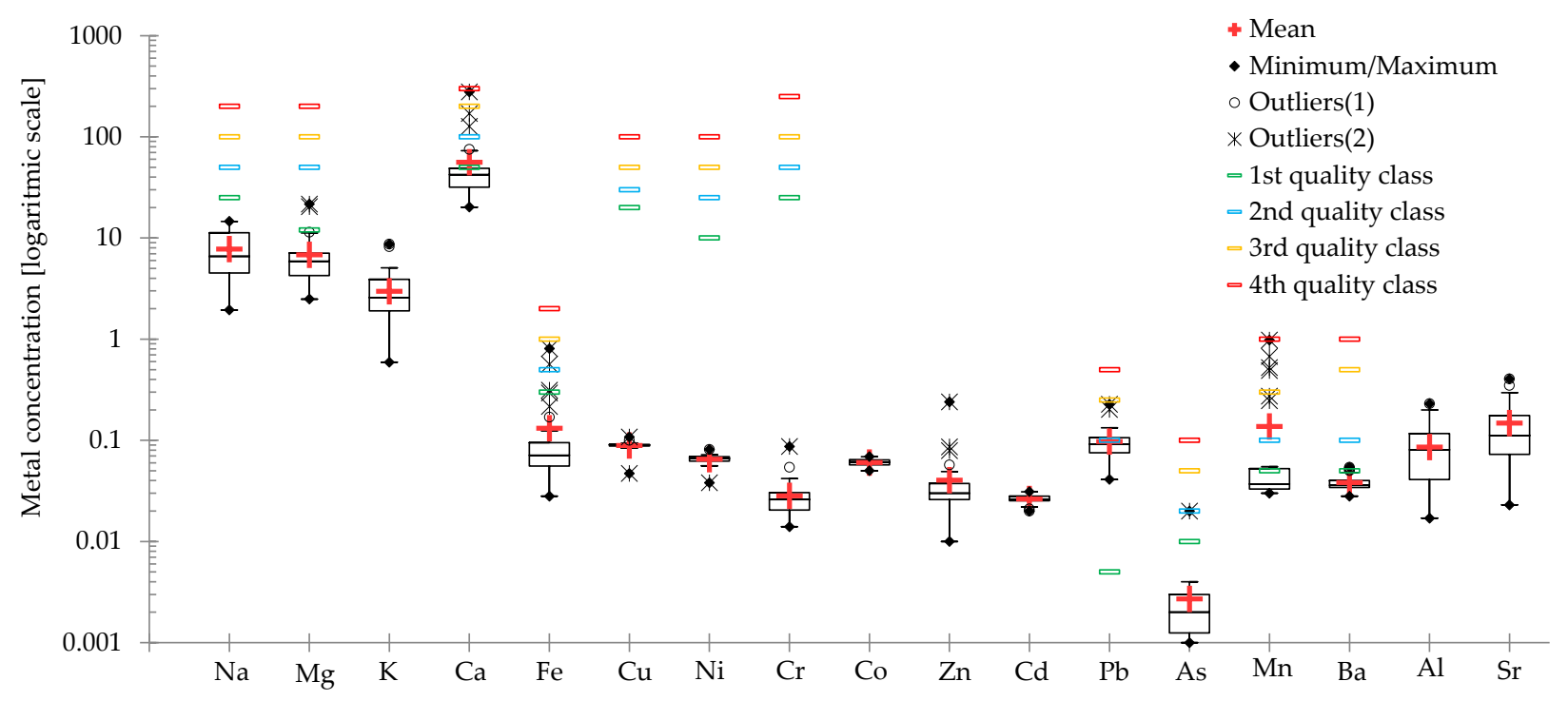

Figure 3. The variation of elements in the sampling sites.

$\mathrm{Cr}, \mathrm{Co}$ and $\mathrm{Zn}$ concentrations were below the limits established by the Romanian and European Regulations regarding the quality of water resources [34,35]. The highest $\mathrm{Cr}$ concentration was $0.087 \mathrm{mg} / \mathrm{L}$ (A14) nearby Baia de Aries (a former mine that stopped its activity in 2004). There are no available data of environmental quality remediation attempts in that area. The $\mathrm{Cu}$ and $\mathrm{Zn}$ concentrations have a low degree of variation: $\mathrm{Cu}$ was in the range of $0.088-0.108 \mathrm{mg} / \mathrm{L}$, and $\mathrm{Zn}$ ranged between 0.010 and $0.240 \mathrm{mg} / \mathrm{L} . \mathrm{Pb}$ (0.041-0.227 $\mathrm{mg} / \mathrm{L}$ ) was identified in samples connected to the tailing impoundments (A7, A9-A15).

$\mathrm{Ni}$, Co and $\mathrm{Cd}$ concentrations had a very low spatial variation, indicating no anthropogenic interference in the water chemistry main processes. Ni ranged from 0.038 to $0.081 \mathrm{mg} / \mathrm{L}$, Co from $0.050 \mathrm{mg} / \mathrm{L}$ to $0.069 \mathrm{mg} / \mathrm{L}$, with the highest value in A11, while Cd concentrations ranged between $0.020 \mathrm{mg} / \mathrm{L}$ and $0.031 \mathrm{mg} / \mathrm{L}$ (A17).

In all studied samples, $\mathrm{Ba}$ and $\mathrm{Al}$ were within the normal limits, Ba ranged between $0.028 \mathrm{mg} / \mathrm{L}$ and $0.054 \mathrm{mg} / \mathrm{L}$ (A11) and Al between $0.033 \mathrm{mg} / \mathrm{L}$ and $0.230 \mathrm{mg} / \mathrm{L}$ (A20). Sr had the maximum value of $0.405 \mathrm{mg} / \mathrm{L}$ in A14, nearby Baia de Aries.

It was noticed that most of the contaminated sampling points with heavy metals were A7, A9, A12 and A13. The water samples sites were connected to Rosia Montana and Rosia Poieni mining areas, indicating a significant impact on the chemical composition of the Aries River catchment over time.

Previous studies conducted in the investigated area highlighted a high degree of pollution of the Abrud River (A9), emissary river of the Sesii Valley (A7) and of the Aries River, in the proximity of Baia de Aries (A13, A14) [10,47]. Relying on previous studies, it can be concluded that, even if the mining activity reduced or stopped operating in the studied area, the water quality did not present major improvements over time. Some studies indicated a long period of time until major improvements in the quality of the environment and surface waters in areas affected by mining activities are reached without any human intervention [48,49]. Thus, before overflowing into the effluent, wastewaters are highly recommended to be pretreated before being released into the environment in order to prevent the destruction of the natural water system and the imminent negative effects on human health. The nitrification, biochemical removal and thiocyanate processes are three successful wastewater treatment methods for addressing the sources of water contaminated by mining effluents [50]. Gonzalez-Merchan et al. [51] proposed an efficient treatment to neutralize the $\mathrm{pH}$ with wet $\mathrm{Fe}(\mathrm{VI})$ synthesized from $\mathrm{Fe}\left(\mathrm{NO}_{3}\right)_{3}, \mathrm{FeCl}_{3}$, or $\mathrm{Fe}_{2}\left(\mathrm{SO}_{4}\right)_{3}$ and removing the toxic elements resulted from mining activities (gold extractions). 


\subsection{Cations and Anions Characteristics}

The river chemistry is generally associated with human and atmospheric inputs: rock and soil weathering, evaporation and crystallization [42,52]. Ca $(56.0 \pm 52.1 \mathrm{mg} / \mathrm{L})$ was the dominant major cation across the Aries River catchment, followed by Na $(7.77 \pm 1.98 \mathrm{mg} / \mathrm{L})$, $\mathrm{Mg}(6.99 \pm 4.52 \mathrm{mg} / \mathrm{L})$ and $\mathrm{K}(2.96 \pm 1.96 \mathrm{mg} / \mathrm{L})$. Na concentration ranged between 1.90 and $14.6 \mathrm{mg} / \mathrm{L}$, with the maximum concentration measured in A27 (Table 4). The highest levels of $\mathrm{Mg}$, $\mathrm{K}$ and $\mathrm{Ca}$ were identified in $\mathrm{A} 7$ and $\mathrm{A} 9$. The $\mathrm{Ca}$ and $\mathrm{Mg}$ concentrations in the water samples from the Aries River catchment were higher than $75 \%$ of the total cation amount from the studied area, reflecting the predominance of carbonate weathering in the surface water. By contrast, $\mathrm{HCO}_{3}{ }^{-}(118 \pm 59.7 \mathrm{mg} / \mathrm{L})$ and $\mathrm{SO}_{4}{ }^{2-}(80.5 \pm 94.8 \mathrm{mg} / \mathrm{L})$ were the most abundant major anions in the surface waters. The main sources of bicarbonate are the weathering and dissolution processes of different rocks, such as calcite, carbonate, silicate and dolomite. The increasing trend of $\mathrm{SO}_{4}{ }^{2-}$ concentration in $\mathrm{A} 7$ was not attributed to natural fluctuations but related to the industrial and agricultural activities in the Aries River catchment. The samples with the lowest $\mathrm{SO}_{4}{ }^{2-}$ concentration are also associated with the lowest TDS values.

The $\mathrm{NO}_{3}{ }^{-}$concentrations ranged between 0.5 and $2.5 \mathrm{mg} / \mathrm{L}$. Generally, the lowest values of $\mathrm{NO}_{3}{ }^{-}$are correlated to the highest TDS values, except for sample A13, which was the richest sample in $\mathrm{NO}_{3}{ }^{-}$and had a high value for the TDS.

Regarding the $\mathrm{Cl}^{-}$concentration, high values were noticed in samples A7 $(42.9 \mathrm{mg} / \mathrm{L})$ and A13 $(45.8 \mathrm{mg} / \mathrm{L})$, while in the rest of the samples, $\mathrm{Cl}^{-}$ranged between 1.19 and $20.8 \mathrm{mg} / \mathrm{L}$. Furthermore, the chloride $\left(\mathrm{Cl}^{-}\right)$concentration indicated a low atmospheric contribution in the river catchment area. The highest $\mathrm{F}^{-}$concentration was determined in sample A13 (0.33 mg/L), while the lowest was in samples A1, A2, A4 and A6.

$\mathrm{NO}_{2}{ }^{-}$and $\mathrm{PO}_{4}{ }^{3-}$ were lower than the quantification limits $(0.05 \mathrm{mg} / \mathrm{L})$ of the method. The low concentrations of anions in the samples A1-A6, A17-A24 were due to the lithology, low human interference and slow weathering rate. The high standard deviations of the anions indicated that the data were usually spread due to the spatial variations among all sites and possible anthropogenic impacts. Other surface waters from Europe are characterized by comparable concentrations of anions, ranging between 0.01 and $0.19 \mathrm{mg} / \mathrm{L} \mathrm{NO}_{2}{ }^{-}$; 4.51 and $6.49 \mathrm{mg} / \mathrm{L} \mathrm{NO}_{3}{ }^{-} ; 0.66$ and $3.33 \mathrm{mg} / \mathrm{L} \mathrm{PO}_{4}{ }^{3-} ; 23.5$ and $265 \mathrm{mg} / \mathrm{L} \mathrm{SO}_{4}{ }^{2-}$ in Coruh River Basin (Georgia and Turkey) and 30.0 and $2000 \mathrm{mg} / \mathrm{L} \mathrm{Cl}^{-}, 0.1$ and $30.0 \mathrm{mg} / \mathrm{L} \mathrm{NO}_{3}{ }^{-}$ and 550 and $1000 \mathrm{mg} / \mathrm{L} \mathrm{SO}_{4}{ }^{2-}$ in El Avenque River (Spain) [53,54].

The high values of EC and TDS and the high concentrations of $\mathrm{HCO}_{3}{ }^{-}, \mathrm{SO}_{4}{ }^{2-}, \mathrm{Mg}$, $\mathrm{K}, \mathrm{Ca}$ and $\mathrm{Pb}$ determined in samples $\mathrm{A} 7, \mathrm{~A} 9$ and $\mathrm{A} 13$ clearly indicated an input of mine drainage from the mining-affected sites. $\mathrm{Ca}$ and $\mathrm{HCO}_{3}{ }^{-}, \mathrm{K}$ and $\mathrm{NO}_{3}{ }^{-}, \mathrm{Mg}$ and $\mathrm{SO}_{4}{ }^{2-}$ were observed to have similar spatial variations (Figure 4). The trend of the highest composition of $\mathrm{Ca}$ and $\mathrm{HCO}_{3}{ }^{-}$in the Aries River was likely primarily derived from the dissolution of dolomite and from the dissolution of calcite (the upper and middle catchment area is represented mostly by karst landscape), while, based on the cation and anion concentrations, four different clusters were obtained. According to the hierarchical cluster analysis (HCA), four clusters were grouped, as indicated in Figure 4. Cluster 1 was formed by samples A7, $\mathrm{A} 10$ and $\mathrm{A} 11$, due to high values of $\mathrm{Ca}$ and $\mathrm{SO}_{4}{ }^{2-}$. Cluster 4 grouped samples A1, A2, A3, A4, A5, A6 and A10, based on the low concentrations of $\mathrm{F}^{-}$, $\mathrm{Cl}^{-}, \mathrm{NO}_{3}{ }^{-}, \mathrm{SO}_{4}{ }^{2-}, \mathrm{Mg}$ and $\mathrm{K}$. A13 and $\mathrm{A} 8$ were not linked to a particular cluster, due to a main characteristic of the sample (in the case of $\mathrm{A} 8$, due to a high concentration of $\mathrm{SO}_{4}{ }^{2-}$ and, in the case of $\mathrm{A} 13$, high concentration of $\mathrm{HCO}_{3}{ }^{-}$). 


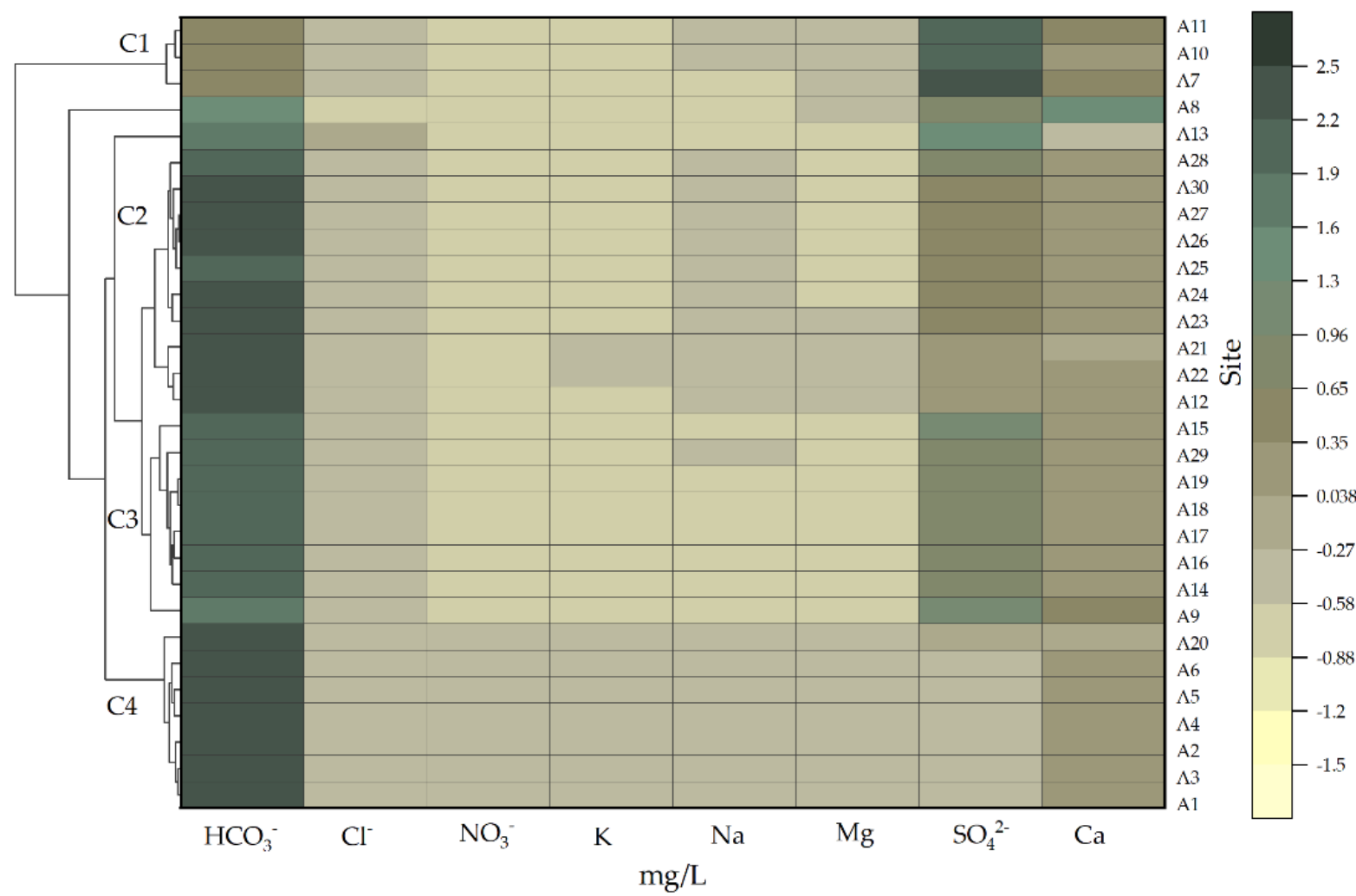

Figure 4. The logarithmic distribution of chemical parameters concentrations $\left(\mathrm{HCO}_{3}{ }^{-}, \mathrm{Cl}^{-}, \mathrm{NO}_{3}{ }^{-}, \mathrm{K}, \mathrm{Na}, \mathrm{Mg}, \mathrm{SO}{ }^{2-}, \mathrm{Ca}\right)$ among the sampling points with the corresponding dendrograms.

The correlations and similarities among the chemical indicators were established with the agglomerative hierarchical cluster analysis. The performed HCA classifies all 30 water samples (A1-A30) into four clusters (Figure 5). Cluster 1 (C1) included $\mathrm{pH}, \mathrm{NO}_{3}{ }^{-}, \mathrm{Al}, \mathrm{Cd}$, $\mathrm{Ni}$ and $\mathrm{Cu}$, Cluster $2(\mathrm{C} 2)$ contained almost all of the anions $\left(\mathrm{Cl}^{-}, \mathrm{F}^{-}, \mathrm{HCO}_{3}{ }^{-}, \mathrm{SO}_{4}{ }^{2-}\right), \mathrm{Ca}$, TDS and EC, while Cluster 3 (C3) included the rest of the cations $(\mathrm{Mg}, \mathrm{K}, \mathrm{Na})$ and most of the metals ( $\mathrm{Sr}, \mathrm{Cr}, \mathrm{Ba}, \mathrm{Fe}, \mathrm{Pb}, \mathrm{Co}, \mathrm{Zn}$ and $\mathrm{Mn}$ ).

$\mathrm{TDS}, \mathrm{SO}_{4}{ }^{2-}$ and $\mathrm{Ca}$ were grouped, suggesting the same source. The high values of TDS were due to the natural dissolution of gypsum or due to anthropogenic activities. $\mathrm{NO}_{3}{ }^{-}$, $\mathrm{Al}, \mathrm{Cd}, \mathrm{Ni}$ and $\mathrm{Cu}(\mathrm{Cl})$, and, respectively, $\mathrm{Cr}, \mathrm{Ba}, \mathrm{Fe}, \mathrm{Pb}, \mathrm{Co}, \mathrm{Zn}$ and $\mathrm{Mn}(\mathrm{C} 3)$ were distant from $\mathrm{EC} / \mathrm{SO}_{4}{ }^{2-}$, indicating that those parameters behave quite differently. Therefore, a possible mechanism of establishing the main processes controlling the chemistry of surface waters was established. Mining activities are a source of toxic metals, while natural processes, such as the weathering of gypsum, could be the main source of $\mathrm{Ca}$ and $\mathrm{SO}_{4}{ }^{2-}$ [55]. $\mathrm{NO}_{3}{ }^{-}, \mathrm{Mn}$ and As were clustered in sample A12, indicating the same source and similar chemical behavior.

The water types of the analyzed samples were determined using the Piper and Durov diagrams (Figure 6a,b). The hydrochemical facies and different types of waters were assessed based on the major cations and anions projected into the diamond field situated in the center of the Piper plot [32,42]. In the cation plot, most of the studied water samples were situated in the left corner, where the Ca concentration was high, indicating its dominance. In contrast, the anion diagram showed that most of the water samples were distributed in the lower-left corner, characterized by the dominance of $\mathrm{HCO}_{3}{ }^{-}$over $\mathrm{Cl}^{-}$ and $\mathrm{SO}_{4}{ }^{2-}$. However, two samples were situated in the upper corner and dominated by $\mathrm{SO}_{4}{ }^{2-}$ over $\mathrm{Cl}^{-}$and $\mathrm{HCO}_{3}{ }^{-}$. 


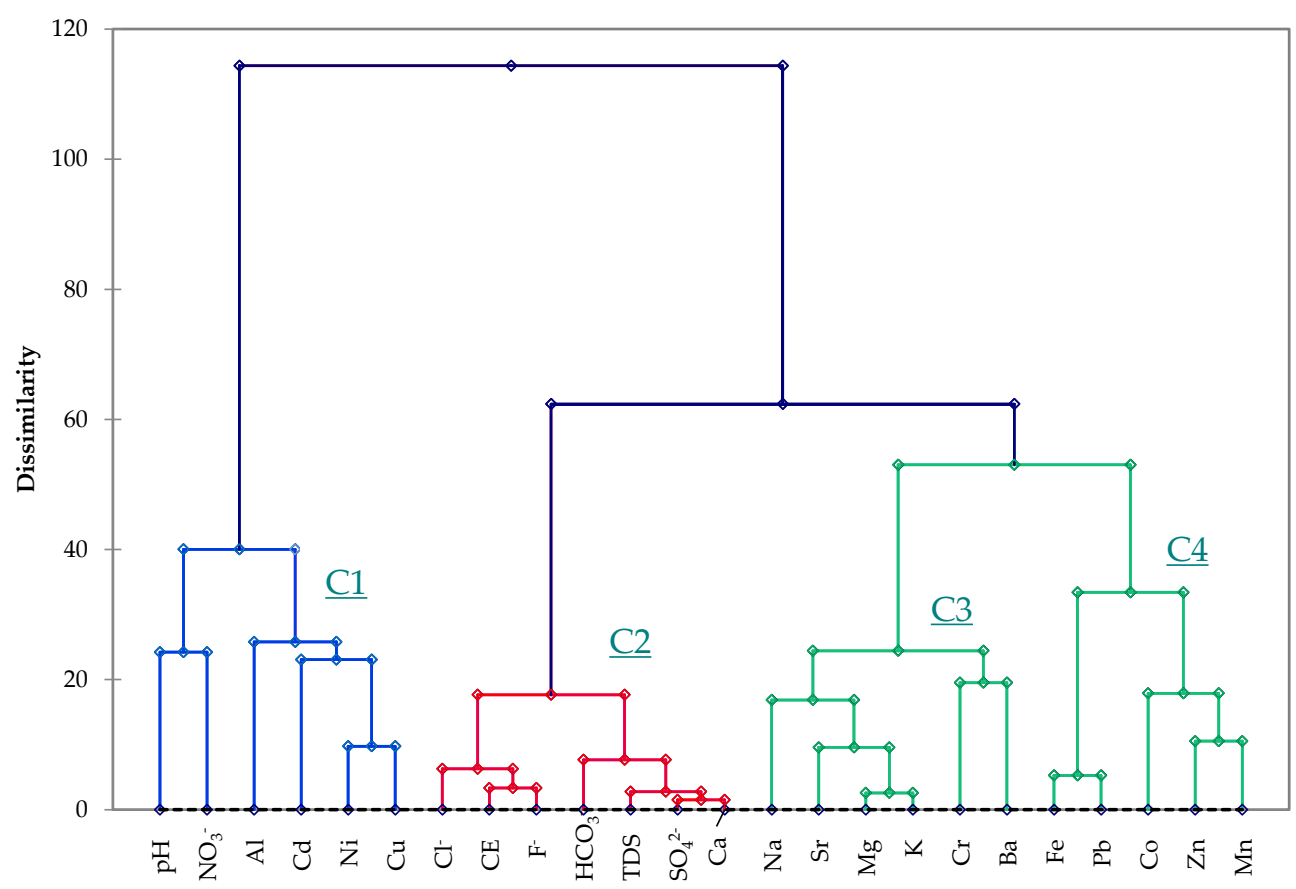

Figure 5. Hierarchical cluster analysis of the physico-chemical indicators for the studied samples.

(a)

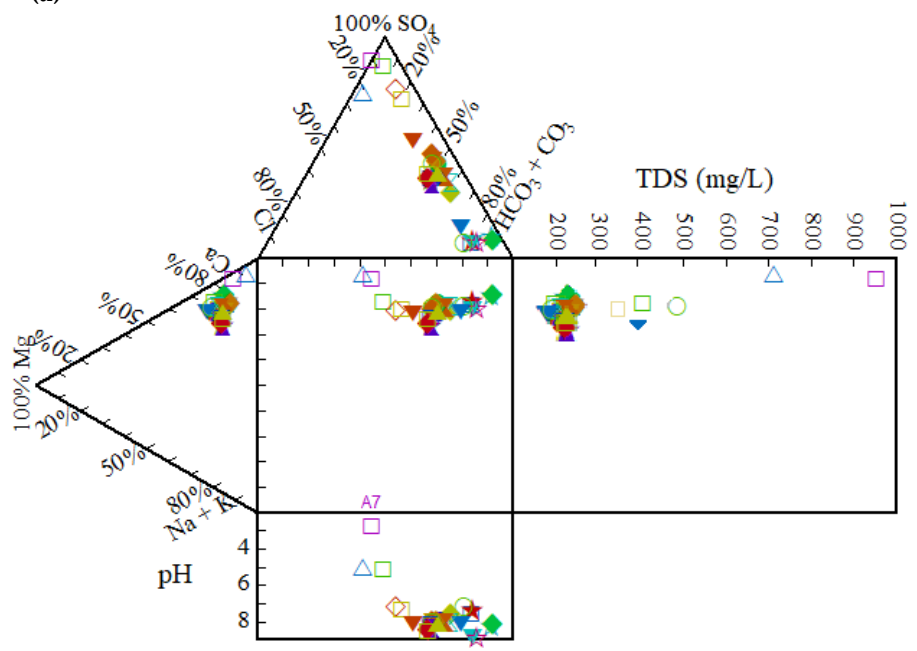

(b)

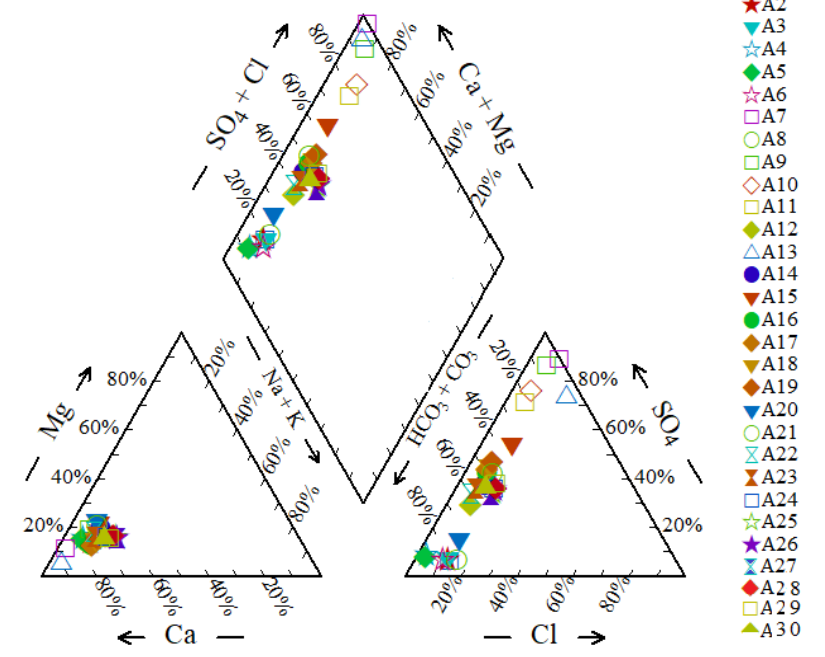

Figure 6. Durov (a) and Piper (b) diagrams describing the water facies of the studied surfacewaters.

The overall characteristics of the chemistry in the surface water samples, according to the Piper diagram, are the dominance of the alkaline earth elements ( $\mathrm{Ca}$ and $\mathrm{Mg}$ ) over the alkaline elements $(\mathrm{Na}$ and $\mathrm{K})$ and for the weak acids $\left(\mathrm{HCO}_{3}{ }^{-}\right)$over the strong acids $\left(\mathrm{SO}_{4}{ }^{2-}+\mathrm{Cl}^{-}\right)$.

The Piper and Durov diagrams showed that the water samples were divided into two main types: $\mathrm{Mg}_{-} \mathrm{HCO}_{3}{ }^{-}$type (A1-A6, A8, A12, A14, A16-A30), indicating their carbonatedominant lithology and $\mathrm{Ca}-\mathrm{Cl}^{-}$type (A7, A9, A10, A11, A13, A15). The Durov plot also indicated that the majority of samples are alkaline, except for A7, A9 and A13, which were characterized by low $\mathrm{pH}$ values. 


\subsection{Pollution Index}

The water quality of the study area was analyzed using several pollution indices. The HPI is used to characterize the potential environmental risk of heavy metals in water bodies, while HEI gives an overall quality of the water regarding the heavy metal concentration [13,38]. The spatial trends for the HPI and HEI in the Aries River catchment were calculated based on the following heavy metals: $\mathrm{Cd}, \mathrm{Cu}, \mathrm{Fe}, \mathrm{Mn}, \mathrm{Ni}, \mathrm{Pb}$ and $\mathrm{Zn}$. The number of heavy metals was reported to the standard values established by the Romanian Legislation, Order 161/2006/OD and Directive 2008/32/CE [34,35].

HEI ranged from 2.65 to 16.9 , indicating a medium level of heavy metal pollution in 5 out of the 30 water samples. The highest HEI results were obtained in the case of A12 $(\mathrm{HEI}=16.9)$, samples collected from the vicinity of Valea Sesii. Based on scaled HEI values, $83 \%$ of samples were classified as having low pollution levels and $17 \%$ with medium pollution levels (Figure $7 b$ ).

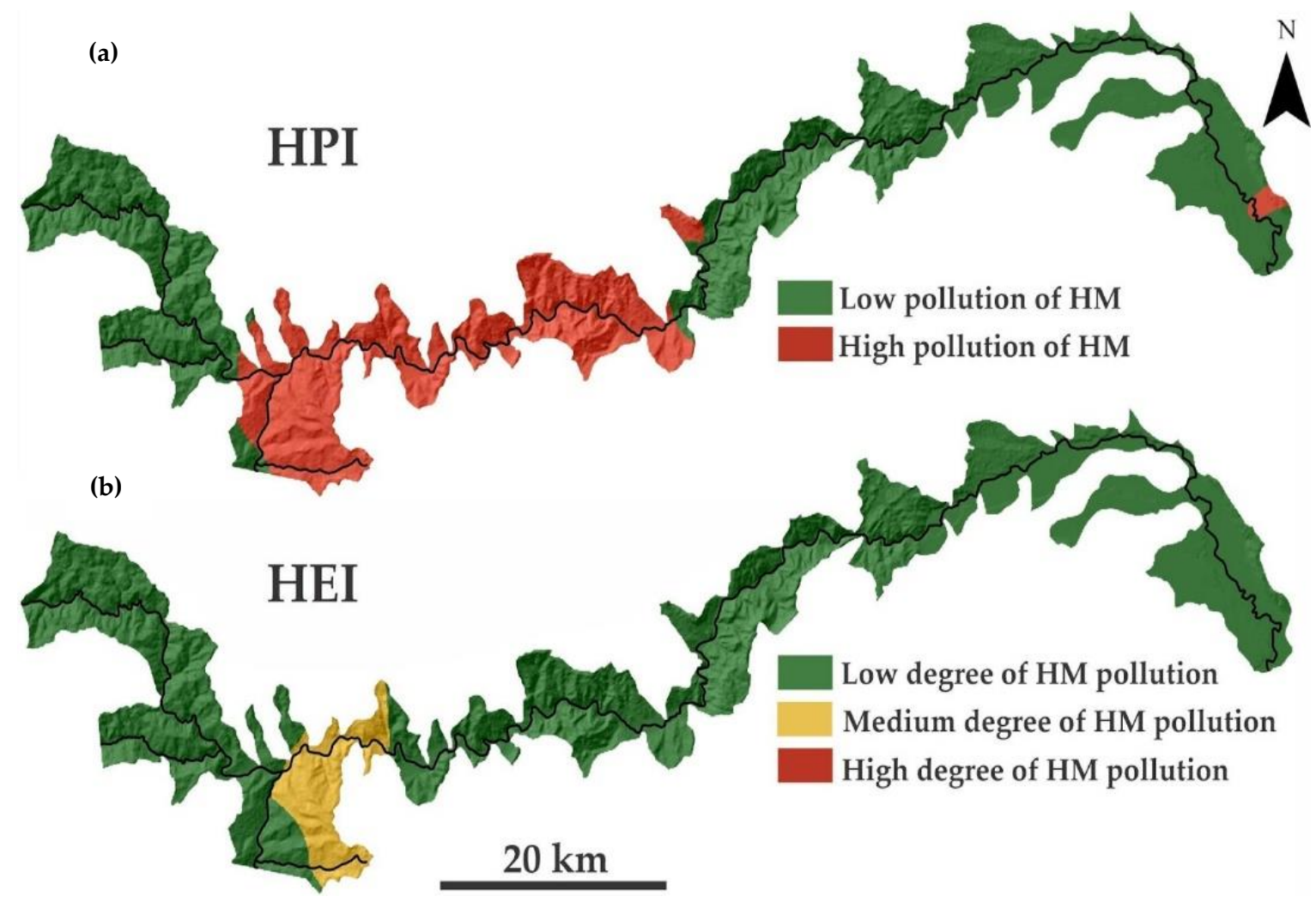

Figure 7. Spatial variation of heavy metal pollution index HPI (a) and heavy metal evaluation index HEI (b).

Studies from Africa indicated low and moderate-heavy metal pollution in the Malopane region (Dorpsrivier, Mogalakwena Deep pool, Dithokeng, Rooisloot, South Africa), a region with intensive agriculture and mining activities [56].

\subsection{Water Quality Index and Vulnerability Assessment}

The WQI provides a single value of expression, which outlines various parameters and gives a measure of the water quality. A number of 15 physico-chemical parameters were used for the calculation of the WQI ( $\mathrm{pH}, \mathrm{TDS}, \mathrm{Cl}^{-}, \mathrm{NO}_{3}{ }^{-}, \mathrm{SO}_{4}{ }^{2-}, \mathrm{Na}, \mathrm{Mg}, \mathrm{Ca}, \mathrm{Cu}$, $\mathrm{Zn}, \mathrm{Pb}, \mathrm{Fe}, \mathrm{Ni}, \mathrm{Mn}$ and $\mathrm{As}$ ). The results ranged from 17.7 to 103 with a mean value of 31.9 (for all 30 samples), and the mean water quality was rated as "good" in general. Spatially, 21 samples were ranked with excellent quality, three samples with good quality (A14, A15, A16), four with medium quality (A9, A10, A11, A13), one sample was characterized by poor quality (A7) and one sample unsuitable for usage (A12). Thus, the WQI scores. were significantly different among the four spatial groups (Figure 8). 


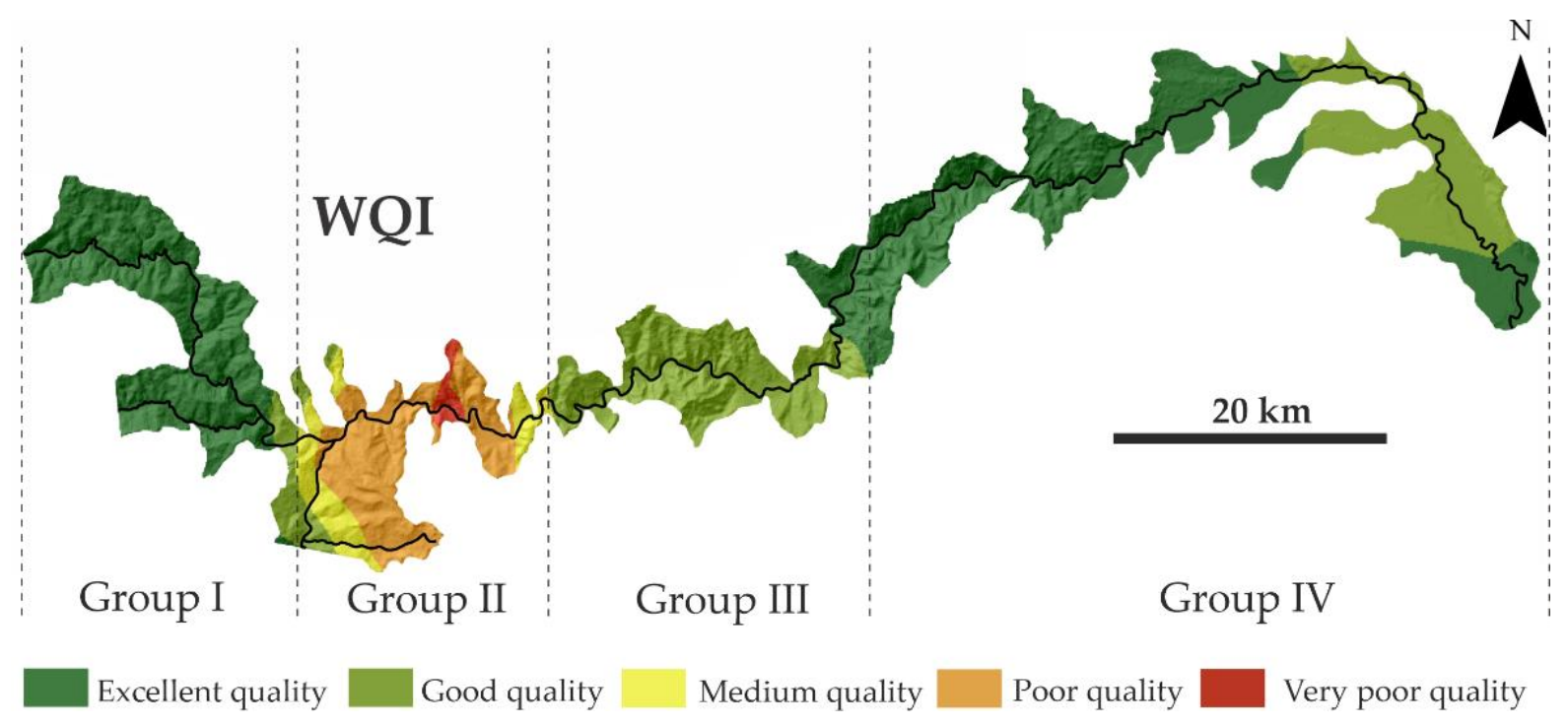

Figure 8. Spatial variation of the water quality index (WQI).

The WQI results were relatively high in Group I (with a mean of 19.1). The second group was characterized by a mean value of 62.9 , with only one sample with a WQI score lower than 50 (WQI < 50). Group II area is localized nearby a tailing impoundment and an industrialized location. The WQI has a mean value of 28.2 in Group II. Water quality improves as the distance from mine drainage sources increases in Groups III and IV. According to the WQI classification, the general water quality state characterizes Group I with excellent quality, Group II with moderate quality and Groups III and IV with good and excellent quality.

The WQI scores obtained from different studies from Africa (Limpopo) range between 121 and 4644, indicating very poor quality water and not suitable for drinking due to the rich precipitation, high ionic activities and sedimentation [56]. In Turkey (Kirmir Basin), according to the WQI results, the studied water samples are characterized by very poor quality due to urbanization and anthropogenic activities; WQI ranged from 7.4 to 38.1 [57]. There were considerable spatial disparities in the assessed vulnerability of surface water resources in the study area.

Covering $\approx 68 \%$ of all the study area, the vulnerability level was generally reduced, especially in the western and eastern regions. In the central area of the Aries catchment, high and very high vulnerability levels were observed, overlapping with the discharge area of the tailing impoundments, washing water flux and all the streams influenced by their tributary's poor-quality status. Similar to the water quality classification based on the WQI, a medium vulnerability level was overlying the area characterized by a quality improvement trend (Group III).

Surface water resources in the Apuseni Mountains are abundant, while the ratio between regional supply and water demand in the study area was relatively small. Due to the historical and current mining activities, agricultural water consumption, and low efficiency of water use, the vulnerability of water resources in the Aries catchment remains high.

\section{Discussion}

On a global scale, acid mine drainage is an important source of surface water pollution. Luis et al. (2009) reported the effects of mine drainage to a hydrographic river catchment in an area characterized by an abundance of sulfide ore bodies from Portugal [45].

The degree of the mineralization process could be reflected by the EC and TDS, which showed variations. The EC and TDS were positively correlated. In the case of samples A7, A8 and A13, the EC and TDS values were in the range of 901-1348 $\mu \mathrm{S} / \mathrm{cm}$ and $712-952 \mathrm{mg} / \mathrm{L}$, respectively. Similar results of $\mathrm{pH}$, TDS and EC were reported in the surface water resources nearby the gold mining areas in Tongon-an open-pit gold mine 
that produced between 2012 and 2015 about $1.356 \times 107$ tons of ores, located in Cote d'Ivoire Region, Africa [58]. In different parts of Europe (Georgia, Spain and Turkey), comparable results were obtained for Coruh and El Avenque Rivers with $\mathrm{pH}$ variation from 4.50 to 9.07 , and EC from 114 to $1200 \mu \mathrm{S} / \mathrm{cm}[53,54]$.

In general, the sources of high amounts of heavy metals are industrial and mining activities [53,54]. Recent studies from Turkey and Georgia show relatively high amounts of heavy metals in surface waters, such as $0.33-2.88 \mu \mathrm{g} / \mathrm{L} \mathrm{Cd} ; 0.7-17.2 \mu \mathrm{g} / \mathrm{L} \mathrm{Co}$;

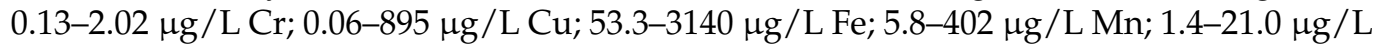
$\mathrm{Ni}$; 0.1-73.0 $\mu \mathrm{g} / \mathrm{L} \mathrm{Pb}$ and 7.6-537 $\mu \mathrm{g} / \mathrm{L} \mathrm{Zn} \mathrm{[53].} \mathrm{While} \mathrm{in} \mathrm{Spain} \mathrm{(El} \mathrm{Avenque} \mathrm{River),} \mathrm{the}$ heavy metal content varied between 0.01 and $1.00 \mathrm{mg} / \mathrm{L} \mathrm{Cd}, 0.01$ and $0.15 \mathrm{mg} / \mathrm{L} \mathrm{Cu}, 0.01$ and $0.25 \mathrm{mg} / \mathrm{L} \mathrm{Pb}$, and 0.01 and $450 \mathrm{mg} / \mathrm{L} \mathrm{Zn} \mathrm{[54].}$

In surface water in China, mining activities influenced the quality of water as well, by increasing the level of metals, the studied waters being characterized by relatively high concentrations of As (0.0-6.90 $\mu \mathrm{g} / \mathrm{L}), \mathrm{Cr}(0.95-42.9 \mu \mathrm{g} / \mathrm{L}), \mathrm{Cu}(1.20-19.0 \mu \mathrm{g} / \mathrm{L}), \mathrm{Mn}$ (2.65-168 $\mu \mathrm{g} / \mathrm{L}), \mathrm{Ni}(1.69-164 \mu \mathrm{g} / \mathrm{L}), \mathrm{Pb}(0.91-28.2 \mu \mathrm{g} / \mathrm{L})$ and $\mathrm{Zn}(2.74-490 \mu \mathrm{g} / \mathrm{L})$ [59].

HPI results were ranging from 68.4 to 412 , as indicated in Table 5, showing some pollution levels with the studied heavy metals. The spatial distribution of HPI results is presented in Figure 7a. The mean value of HPI results was 132, indicating a concerning risk of pollution with the analyzed heavy metals in the study area, more specifically with $\mathrm{Pb}, \mathrm{Mn}$ and Fe. Different studies from Serbia (Ugljesnica River) and India (Bokaro River) indicated no heavy metal pollution with $\mathrm{Cd}, \mathrm{Cu}, \mathrm{Fe}, \mathrm{Mn}, \mathrm{Pb}, \mathrm{Zn}$ with $\mathrm{HPI}$ scores. ranging from 66 to 90 and 2.0 to $26[14,15]$ although the rivers are located nearby mining areas. In Nigeria (Commodore channel) and China (Houjing River), the HPI results ranged between 985 and 5995, and 100 and 230, indicating high amounts of heavy metals due to industrial (wastewaters, landfill leachate) and household activities [60,61].

Table 5. Results of the calculated pollution and quality indices (HPI, HEI and WQI).

\begin{tabular}{|c|c|c|c|}
\hline & HPI & HEI & WQI \\
\hline A1 & 91.4 & 3.50 & 17.9 \\
\hline $\mathrm{A} 2$ & 100 & 3.72 & 18.4 \\
\hline A3 & 109 & 4.38 & 22.6 \\
\hline A4 & 96.2 & 3.53 & 17.7 \\
\hline A5 & 87.7 & 3.48 & 18.8 \\
\hline A6 & 78.7 & 3.31 & 19.4 \\
\hline A7 & 256 & 10.3 & 78.9 \\
\hline A8 & 68.9 & 2.65 & 18.8 \\
\hline A9 & 247 & 10.5 & 62.5 \\
\hline A10 & 229 & 10.2 & 63.0 \\
\hline A11 & 257 & 11.0 & 66.7 \\
\hline A12 & 412 & 16.9 & 103 \\
\hline A13 & 188 & 7.07 & 46.7 \\
\hline A14 & 117 & 4.24 & 25.1 \\
\hline A15 & 113 & 4.18 & 25.8 \\
\hline A16 & 150 & 5.94 & 33.6 \\
\hline A17 & 125 & 4.62 & 23.5 \\
\hline A18 & 121 & 4.62 & 24.2 \\
\hline A19 & 69.6 & 3.72 & 26.2 \\
\hline A20 & 107 & 4.06 & 21.1 \\
\hline A21 & 99.5 & 3.78 & 20.9 \\
\hline A22 & 80.2 & 3.17 & 19.4 \\
\hline A23 & 102 & 3.70 & 21.5 \\
\hline A24 & 99.3 & 3.56 & 22.1 \\
\hline A25 & 99.9 & 3.58 & 23.1 \\
\hline A26 & 87.5 & 3.45 & 23.4 \\
\hline A27 & 68.4 & 3.06 & 23.7 \\
\hline A28 & 99.7 & 3.75 & 23.3 \\
\hline A29 & 113 & 4.11 & 23.2 \\
\hline A30 & 80.7 & 3.24 & 21.8 \\
\hline
\end{tabular}




\section{Conclusions}

According to the obtained results, the studied water system (Aries River) was characterized as vulnerable in the presence of mining activities and "historical" pollution.

The mean concentrations of the major ions were in the following order: $\mathrm{Ca}>\mathrm{Na}>$ $\mathrm{Mg}>\mathrm{K}, \mathrm{HCO}_{3}{ }^{-}>\mathrm{SO}_{4}{ }^{2-}>\mathrm{Cl}^{-}>\mathrm{NO}_{3}{ }^{-}>\mathrm{F}^{-}$, indicating that both natural processes and anthropogenic activities conducted in the study area played an important role in the water quality.

Neutral-alkaline and acid waters characterized the studied water according to the Durov and Piper plots, indicating low water quality. The similarities among the studied physico-chemical indicators given by the HCA indicated the sources of water pollution (natural and anthropogenic) and the low quality of water, respectively.

Even if, in general, the heavy metals concentration was not considered to be higher than the MACs, except for $\mathrm{Fe}, \mathrm{Mn}$ and $\mathrm{Pb}$, the HPI scores. revealed a relatively high degree of heavy metals pollution in all the studied samples, while the HEI indicated low to high levels of heavy metal pollution in the studied water samples, due to high $\mathrm{Fe}, \mathrm{Mn}$ and $\mathrm{Pb}$ concentrations. According to the WQI, the water quality was classified as excellent, good (A14, A15, A16), medium (A9, A10, A11, A13), poor (A7) and very poor (A12).

Generally, the obtained results showed contamination with metals, especially with $\mathrm{As}, \mathrm{Fe}, \mathrm{Mn}$ and $\mathrm{Pb}$, indicating a degree of vulnerability for the water from the Aries River catchment in front of the mining activities, with historical pollution still present. Furthermore, the Aries River needs immediate quality monitoring and proper treatment in order to prevent hazards and human healthfrom being affected. Thus, the obtained results could be very useful to the local authorities in implementing a sustainable and appropriate management strategy, indicating the clear vulnerability of the water system.

Author Contributions: Conceptualization, A.M., O.C. and V.M.; methodology, A.M., M.-A.H., R.B., O.C. and A.I.T.; sampling, M.R.; analysis, O.C., M.-A.H., A.M. and A.I.T.; visualization, A.M., A.I.T. and I.C.M.; writing—original draft preparation, A.M., M.-A.H., A.I.T. and I.C.M.; writing-review and editing, A.M., M.-A.H. and O.C.; funding acquisition, O.C. All authors have read and agreed to the published version of the manuscript.

Funding: This paper was supported by the Project "Entrepreneurial competences and excellence research in doctoral and postdoctoral programs-ANTREDOC", a project co-funded by the European Social Fund and The Competitiveness Operational Programme of the Ministry of European Funds, code MY SMIS 107874.

Institutional Review Board Statement: Not applicable.

Informed Consent Statement: Not applicable.

Data Availability Statement: The data presented in this study is available on request from the corresponding author.

Conflicts of Interest: The authors declare no conflict of interest.

\section{References}

1. UNESCO WWAP. The United Nations World Water Development Report, 2017: Wastewater: The Untapped Resource; UNESCO: Paris, France, 2017.

2. UNESCO WWAP. The United Nations World Water Development Report 2016: Water and Jobs; UNESCO: Paris, France, 2016.

3. Miclean, M.; Cadar, O.; Roman, C.; Tanaselia, C.; Stefanescu, L.; Stezar, C.I.; Groza, I.S. The Influence of Environmental Contamination on Heavy Metals and Organochlorine Compounds Levels in Milk. Environ. Eng. Manag. J. 2011, 10, 37-42. [CrossRef]

4. Bonotto, D.M. Hydrogeochemical study of surface waters from Araxá city, Minas Gerais State, Brazil. J. Geochem. Explor. 2020, 213, 106521. [CrossRef]

5. Cadar, O.; Miclean, M.; Cadar, S.; Toselia, C.; Senila, L.; Senila, M. Assessment of heavy metals in cows milk in Rodnei Mountains Area, Romania. Environ. Eng. Manag. J. 2015, 14, 2523-2528. [CrossRef]

6. Protano, G.; Nannoni, F. Influence of ore processing activity on $\mathrm{Hg}$, As and $\mathrm{Sb}$ contamination and fractionation in soils in a former mining site of Monte Amiata ore district (Italy). Chemosphere 2018, 199, 320-330. [CrossRef] 
7. Hoaghia, M.-A.; Cadar, O.; Levei, E.; Roman, C.; Senila, L.; Ristoiu, D. Assessment of potential contamination and health risk associated with metals in drinking waters from Copsa Mica region. Food Environ. Saf. 2015, XIV, 276-281.

8. Bird, G.; Brewer, P.A.; Macklin, M.G.; Serban, M.; Balteanu, D.; Driga, B. Heavy metal contamination in the Arieş river catchment, western Romania: Implications for development of the Roşia Montană gold deposit. J. Geochem. Explor. 2005, 86, 26-48. [CrossRef]

9. Levei, E.; Ponta, M.; Senila, M.; Miclean, M.; Frentiu, T. Assessment of contamination and origin of metals in mining affected river sediments: A case study of the Aries River catchment, Romania. J. Serb. Chem. Soc. 2014 79, 1019-1036. [CrossRef]

10. Senila, M.; Levei, E.A.; Senila, L.R.; Roman, M. Preliminary Investigation concerning Metals Bioavailability in Waters of Aries River Catchment by Using the Diffusive Gradients in Thin Films Technique. J. Chem. 2015, 2015, 762121. [CrossRef]

11. Butiuc-Keul, A.; Momeu, L.; Craciunas, C.; Dobrota, C.; Cuna, S.; Balas, G. Physico-chemical and biological studies on water from Aries River (Romania). J. Environ. Manag. 2012, 95, S3-S8. [CrossRef] [PubMed]

12. Rzymski, P.; Klimaszyk, P.; Marszelewski, W.; Borowiak, D.; Mleczek, M.; Nowiński, K.; Pius, B.; Niedzielski, P.; Poniedziałek, B. The chemistry and toxicity of discharge waters from copper mine tailing impoundment in the valley of the Apuseni Mountains in Romania. Environ. Sci. Pollut. Res. 2017, 24, 21445-21458. [CrossRef] [PubMed]

13. Prasad, B.; Bose, J. Evaluation of the heavy metal pollution index for surface and spring water near a limestone mining area of the lower Himalayas. Environ. Geol. 2001, 41, 183-188. [CrossRef]

14. Milivojević, J.; Krstić, D.; Šmit, B.; Djekić, V. Assessment of Heavy Metal Contamination and Calculation of Its Pollution Index for Uglješnica River, Serbia. Bull. Environ. Contam. Toxicol. 2016, 97, 737-742. [CrossRef] [PubMed]

15. Tiwari, A.K.; De Maio, M.; Singh, P.K.; Mahato, M.K. Evaluation of Surface Water Quality by Using GIS and a Heavy Metal Pollution Index (HPI) Model in a Coal Mining Area, India. Bull. Environ. Contam. Toxicol. 2015, 95, 304-310. [CrossRef]

16. Horton, R.K. An index-number system for rating water quality. J. Water Pollut. Control Fed 1965, 37, 300-306.

17. Adimalla, N.; Qian, H. Groundwater quality evaluation using water quality index (WQI) for drinking purposes and human health risk (HHR) assessment in an agricultural region of Nanganur, south India. Ecotox. Environl. Saf. 2019, 176, 153-161. [CrossRef]

18. Wang, J.; Fu, Z.; Qiao, H.; Liu, F. Assessment of eutrophication and water quality in the estuarine area of Lake Wuli, Lake Taihu, China. Sci. Total Environ. 2019, 650, 1392-1402. [CrossRef]

19. Sener, S.; Sener, E.; Davraz, A. Evaluation of water quality using water quality index (WQI) method and GIS in Aksu River (SW-Turkey). Sci. Total Environ. 2017, 584-585, 131-144. [CrossRef]

20. Luca, E.; Chintoanu, M.; Roman, C.; Văşcan, D.; Luca, L.; Puşcaş, A.; Hoban, A. The identification of the sources of pollution from the Aries basin. Bull. Univ. Agric. Sci. Vet. Med. Cluj-Napoca Hortic. 2006, 63. [CrossRef]

21. Steblez, W.G. The Mineral Industry of ROMANIA. U.S. Geological Survey Minerals Yearbook-1994-1999. Available online: https: / / www.usgs.gov / centers/nmic/europe-and-central-eurasia\#ro (accessed on 10 May 2021).

22. Bilaşco, Ș.; Cocean, P.; Nicula, G.; Drăgan, M. Conditionarea morfometrica a pretabilitatii de amenajare teritoriala in bazinul vaii Ariesului [Morphometric conditioning of territorial planning possibility in the Arieş river basin]. Geogr. Napoc. 2013, 7, 21-35.

23. Petrea, D.; Bilașco, S.; Rosca, S.; Vescan, I.; Fodorean, I. The determination of the landslide occurrence probability by GIS spatial analysis of the land morphometric characteristics (Case Study: The Transylvanian Plateau). Carpath J. Earth Environ. Sci. 2014, 9 , 91-102.

24. Pawlewicz, M.J.; Finn, T.M. Vitrinite Reflectance Data for the Greater Green River Basin, Southwestern Wyoming, Northwestern Colorado, and Northeastern Utah. U.S. Geological Survey Open-File Report 2002. Available online: https://pubs.usgs.gov/of/2002/ofr-02-033 9/ofr-02-0339.pdf (accessed on 27 January 2021).

25. Banaduc, D.; Curtean-Banaduc, A.; Cianfaglione, K.; Akeroyd, J.R.; Cioca, L.I. Proposed Environmental Risk Management Elements in a Carpathian Valley Basin, within the Rosia Montana European Historical Mining Area. Int. J. Environ. Res. Public Health 2021, 18, 4565. [CrossRef]

26. Stefanescu, L.; Costan, C.; Ozunu, A. Riscuri asociate stabilităţii iazurilor de decantare din bazinul mijlociu al Râului Arieş- in Romanian. ProEnvironment 2010, 3, 598-607.

27. Levei, E.; Frentiu, T.; Ponta, M.; Tanaselia, C.; Borodi, G. Characterization and assessment of potential environmental risk of tailings stored in seven impoundments in the Aries river basin, Western Romania. Chem. Cent J. 2013, 7, 5. [CrossRef] [PubMed]

28. Friedel, M.J.; Tindall, J.A.; Sardan, D.; Fey, D.L.; Poputa, G.L. Reconnaissance Study of Water Quality in the Mining-Affected Aries River Basin, Romania, 2331-1258. 2008.

29. Hoaghia, M.-A.; Moldovan, A.; Kovacs, E.; Mirea, I.; Kenesz, M.; Brad, T.; Cadar, O.; Micle, V.; Levei, E.; Moldovan, O. Water Quality and Hydrogeochemical Characteristics of Some Karst Water Sources in Apuseni Mountains, Romania. Water 2021, 13, 857. [CrossRef]

30. Moldovan, A.; Hoaghia, M.-A.; Kovacs, E.; Mirea, I.C.; Kenesz, M.; Arghir, R.A.; Petculescu, A.; Levei, E.A.; Moldovan, O.T. Quality and Health Risk Assessment Associated with Water Consumption-A Case Study on Karstic Springs. Water 2020, 12, 3510. [CrossRef]

31. Rosca, O.M.; Dippong, T.; Marian, M.; Mihali, C.; Mihalescu, L.; Hoaghia, M.A.; Jelea, M. Impact of anthropogenic activities on water quality parameters of glacial lakes from Rodnei mountains, Romania. Environ. Res. 2020, 182, 109136. [CrossRef]

32. Qu, L.; Huang, H.; Xia, F.; Liu, Y.; Dahlgren, R.A.; Zhang, M.; Mei, K. Risk analysis of heavy metal concentration in surface waters across the rural-urban interface of the Wen-Rui Tang River, China. Environ. Pollut. 2018, 237, 639-649. [CrossRef] [PubMed] 
33. Appiah-Opong, R.; Ofori, A.; Ofosuhene, M.; Ofori-Attah, E.; Nunoo, F.K.E.; Tuffour, I.; Gordon, C.; Arhinful, D.K.; Nyarko, A.K.; Fosu-Mensah, B.Y. Heavy metals concentration and pollution index (HPI) in drinking water along the southwest coast of Ghana. Appl. Water Sci. 2021, 11. [CrossRef]

34. ORDER, No. 161 for the Approval of the Norm Regarding the Classification of Surface Water Quality in Order to Establish the Ecological Status of Water Bodies. Available online: http://www.monitoruljuridic.ro/monitorul-oficial/161/2006-02-21 (accessed on 15 April 2021).

35. Directive 2008/32/EC of the European Parliament and of the Council of 11 March 2008 amending Directive 2000/60/EC Establishing a Framework for Community Action in the Field of Water Policy, as Regards the Implementing Powers Conferred on the Commission OJ L 81. 20 May 2008, pp. 60-61. Available online: https:/ / eur-lex.europa.eu/legal-content/EN/ALL/?uri= celex:32008L0032 (accessed on 15 April 2021).

36. Wator, K.; Zdechlik, R. Application of water quality indices to the assessment of the effect of geothermal water discharge on river water quality-Case study from the Podhale region (Southern Poland). Ecol. Indic. 2021, 121. [CrossRef]

37. Bhuiyan, M.A.; Islam, M.A.; Dampare, S.B.; Parvez, L.; Suzuki, S. Evaluation of hazardous metal pollution in irrigation and drinking water systems in the vicinity of a coal mine area of northwestern Bangladesh. J. Hazard. Mater. 2010, 179, 1065-1077. [CrossRef] [PubMed]

38. Edet, A.E.; Offiong, O.E. Evaluation of water quality pollution indices for heavy metal contamination monitoring. A study case from Akpabuyo-Odukpani area, Lower Cross River Basin (southeastern Nigeria). GeoJournal 2002, 57, 295-304. [CrossRef]

39. Karaouzas, I.; Kapetanaki, N.; Mentzafou, A.; Kanellopoulos, T.D.; Skoulikidis, N. Heavy metal contamination status in Greek surface waters: A review with application and evaluation of pollution indices. Chemosphere 2021, 263, 128192. [CrossRef]

40. Nong, X.; Shao, D.; Zhong, H.; Liang, J. Evaluation of water quality in the South-to-North Water Diversion Project of China using the water quality index (WQI) method. Water Res. 2020, 178, 115781. [CrossRef] [PubMed]

41. Mahadevan, H.; Krishnan, K.A.; Pillai, R.R.; Sudhakaran, S. Assessment of urban river water quality and developing strategies for phosphate removal from water and wastewaters: Integrated monitoring and mitigation studies. SN Appl. Sci. 2020, 2. [CrossRef]

42. Pant, R.R.; Zhang, F.; Rehman, F.U.; Wang, G.; Ye, M.; Zeng, C.; Tang, H. Spatiotemporal variations of hydrogeochemistry and its controlling factors in the Gandaki River Basin, Central Himalaya Nepal. Sci. Total Environ. 2018, 622-623, 770-782. [CrossRef] [PubMed]

43. Numanbakth, M.A.A.; Howladar, M.F.; Faruque, M.O.; Sohail, M.A.; Rahman, M.M. Understanding the hydrogeochemical characteristics of natural water for irrigation use around the hard rock mine in Maddhapara, Northwest Bangladesh. Groundw. Sustain. Dev. 2019, 8, 590-605. [CrossRef]

44. Mirzaei, R.; Sakizadeh, M. Comparison of interpolation methods for the estimation of groundwater contamination in AndimeshkShush Plain, Southwest of Iran. Environ. Sci. Pollut. Res. Int. 2016, 23, 2758-2769. [CrossRef]

45. Luís, A.T.; Teixeira, P.; Almeida, S.F.P.; Ector, L.; Matos, J.X.; Ferreira da Silva, E.A. Impact of Acid Mine Drainage (AMD) on Water Quality, Stream Sediments and Periphytic Diatom Communities in the Surrounding Streams of Aljustrel Mining Area (Portugal). Water Air Soil Pollut. 2008, 200, 147-167. [CrossRef]

46. Rakotondrabe, F.; Ngoupayou, J.R.N.; Mfonka, Z.; Rasolomanana, E.H.; Nyangono Abolo, A.J.; Asone, B.L.; Ako Ako, A.; Rakotondrabe, M.H. Assessment of Surface Water Quality of Bétaré-Oya Gold Mining Area (East-Cameroon). J. Water Resource Prot 2017, 09, 960-984. [CrossRef]

47. Levei, E.; Senila, M.; Miclean, M.; Abraham, B.; Roman, C.; Stefanescu, L.; Moldovan, O.T. Influence of Rosia Poieni and Rosia Montana Mining Areas on the Water Quality of the Aries River. Environ. Eng. Manag. J. 2011, 10, 23-29. [CrossRef]

48. Son, J.; Kim, J.G.; Hyun, S.; Cho, K. Screening level ecological risk assessment of abandoned metal mines using chemical and ecotoxicological lines of evidence. Environ. Pollut. 2019, 249, 1081-1090. [CrossRef]

49. Wang, P.; Sun, Z.; Hu, Y.; Cheng, H. Leaching of heavy metals from abandoned mine tailings brought by precipitation and the associated environmental impact. Sci. Total Environ. 2019, 695, 133893. [CrossRef]

50. Di Biase, A.; Wei, V.; Kowalski, M.S.; Bratty, M.; Hildebrand, M.; Jabari, P.; Devlin, T.R.; Oleszkiewicz, J.A. Ammonia, thiocyanate, and cyanate removal in an aerobic up-flow submerged attached growth reactor treating gold mine wastewater. Chemosphere 2020, 243, 125395. [CrossRef] [PubMed]

51. Gonzalez-Merchan, C.; Genty, T.; Paquin, M.; Gervais, M.; Bussière, B.; Potvin, R.; Neculita, C.M. Influence of ferric iron source on ferrate's performance and residual contamination during the treatment of gold mine effluents. Miner. Eng. 2018, 127, 61-66. [CrossRef]

52. Wang, B.; Lee, X.-Q.; Yuan, H.-L.; Zhou, H.; Cheng, H.-G.; Cheng, J.-Z.; Zhou, Z.-H.; Xing, Y.; Fang, B.; Zhang, L.-K.; et al. Distinct patterns of chemical weathering in the drainage basins of the Huanghe and Xijiang River, China: Evidence from chemical and Sr-isotopic compositions. J. Asian Earth Sci. 2012, 59, 219-230. [CrossRef]

53. Bilgin, A.; Konanç, M.U. Evaluation of surface water quality and heavy metal pollution of Coruh River Basin (Turkey) by multivariate statistical methods. Environ. Earth Sci. 2016, 75. [CrossRef]

54. Zornoza, R.; Carmona, D.M.; Acosta, J.A.; Martínez-Martínez, S.; Weiss, N.; Faz, Á. The Effect of Former Mining Activities on Contamination Dynamics in Sediments, Surface Water and Vegetation in El Avenque Stream, SE Spain. Water Air Soil Pollut. 2011, 223, 519-532. [CrossRef]

55. Yaraghi, N.; Ronkanen, A.-K.; Torabi Haghighi, A.; Aminikhah, M.; Kujala, K.; Kløve, B. Impacts of gold mine effluent on water quality in a pristine sub-Arctic river. J. Hydrol. 2020, 589. [CrossRef] 
56. Molekoa, M.; Avtar, R.; Kumar, P.; Thu Minh, H.; Dasgupta, R.; Johnson, B.; Sahu, N.; Verma, R.; Yunus, A. Spatio-Temporal Analysis of Surface Water Quality in Mokopane Area, Limpopo, South Africa. Water 2021, 13, 220. [CrossRef]

57. Tunc Dede, O.; Telci, I.T.; Aral, M.M. The Use of Water Quality Index Models for the Evaluation of Surface Water Quality: A Case Study for Kirmir Basin, Ankara, Turkey. Water Qual. Expo. Health 2013, 5, 41-56. [CrossRef]

58. Sako, A.; Semdé, S.; Wenmenga, U. Geochemical evaluation of soil, surface water and groundwater around the Tongon gold mining area, northern Côte d'Ivoire, West Africa. J. Afr. Earth Sci. 2018, 145, 297-316. [CrossRef]

59. Wei, W.; Ma, R.; Sun, Z.; Zhou, A.; Bu, J.; Long, X.; Liu, Y. Effects of Mining Activities on the Release of Heavy Metals (HMs) in a Typical Mountain Headwater Region, the Qinghai-Tibet Plateau in China. Int. J. Environ. Res. Public Health 2018, $15,1987$. [CrossRef] [PubMed]

60. Charles, I.A.; Nubi, O.A.; Adelopo, A.O.; Oginni, E.T. Heavy metals pollution index of surface water from Commodore channel, Lagos, Nigeria. Afr. J. Environ. Sci. Technol. 2018, 12, 191-197. [CrossRef]

61. Yeh, G.; Hoang, H.G.; Lin, C.; Bui, X.T.; Tran, H.T.; Shern, C.C.; Vu, C.T. Assessment of heavy metal contamination and adverse biological effects of an industrially affected river. Environ. Sci. Pollut. Res. Int. 2020, 27, 34770-34780. [CrossRef] [PubMed] 